\title{
Melting of the primitive martian mantle at 0.5-2.2 GPa and the origin of basalts and alkaline rocks on Mars
}

\author{
Max Collinet ${ }^{\mathrm{a}, \mathrm{b}, *}$, Etienne Médard $^{\mathrm{c}}$, Bernard Charlier $^{\mathrm{b}, \mathrm{d}}{ }^{\text {, Jacqueline Vander Auwera }}{ }^{\mathrm{b}}$, \\ Timothy L. Grove ${ }^{a}$ \\ a Massachusetts Institute of Technology, Department of Earth, Atmospheric and Planetary Sciences, Cambridge, MA, USA \\ ${ }^{\mathrm{b}}$ University of Liege, Department of Geology, 4000 Liege, Belgium \\ ${ }^{c}$ Laboratoire Magmas et Volcans, Université Blaise Pascal - CNRS - IRD, OPGC, 5 rue Kessler, 63038 Clermont-Ferrand, France \\ d Leibniz Universität Hannover, Institut für Mineralogie, 30167 Hannover, Germany
}

\section{A R T I C L E I N F O}

\section{Article history:}

Received 7 February 2015

Received in revised form 23 June 2015

Accepted 26 June 2015

Available online $\mathrm{xxxx}$

Editor: C. Sotin

\section{Keywords:}

alkali basalts

martian crust

mantle solidus

primary melts

primitive melts

\begin{abstract}
A B S T R A C T
We have performed piston-cylinder experiments on a primitive martian mantle composition between 0.5 and $2.2 \mathrm{GPa}$ and 1160 to $1550^{\circ} \mathrm{C}$. The composition of melts and residual minerals constrain the possible melting processes on Mars at 50 to $200 \mathrm{~km}$ depth under nominally anhydrous conditions. Silicate melts produced by low degrees of melting $(<10 \mathrm{wt} . \%)$ were analyzed in layers of vitreous carbon spheres or in micro-cracks inside the graphite capsule. The total range of melt fractions investigated extends from 5 to $50 \mathrm{wt} . \%$, and the liquids produced display variable $\mathrm{SiO}_{2}$ (43.7-59.0 wt.\%), $\mathrm{MgO}(5.3-18.6 \mathrm{wt} . \%)$ and $\mathrm{Na}_{2} \mathrm{O}$ $+\mathrm{K}_{2} \mathrm{O}$ (1.0-6.5 wt.\%) contents. We provide a new equation to estimate the solidus temperature of the martian mantle: $T\left({ }^{\circ} \mathrm{C}\right)=1033+168.1 P(\mathrm{GPa})-14.22 \mathrm{P}^{2}(\mathrm{GPa})$, which places the solidus $50^{\circ} \mathrm{C}$ below that of fertile terrestrial peridotites. Low- and high-degree melts are compared to martian alkaline rocks and basalts, respectively. We suggest that the parental melt of Adirondack-class basalts was produced by $\sim 25$ wt.\% melting of the primitive martian mantle at $1.5 \mathrm{GPa}(\sim 135 \mathrm{~km})$ and $\sim 1400{ }^{\circ} \mathrm{C}$. Despite its brecciated nature, NWA 7034/7533 might be composed of material that initially crystallized from a primary melt produced by $\sim 10-30 \mathrm{wt} . \%$ melting at the same pressure. Other igneous rocks from Mars require mantle reservoirs with different $\mathrm{CaO} / \mathrm{Al}_{2} \mathrm{O}_{3}$ and $\mathrm{FeO} / \mathrm{MgO}$ ratios or the action of fractional crystallization. Alkaline rocks can be derived from mantle sources with alkali contents $(\sim 0.5$ wt.\%) similar to the primitive mantle.
\end{abstract}

(C) 2015 Elsevier B.V. All rights reserved.

\section{Introduction}

Remote analyses by rovers and orbiting spacecraft as well as the compositions of shergottites, the most abundant group of martian meteorites, suggested that the surface of Mars is mainly covered by iron-rich tholeiitic basalts (McSween et al., 2009). Further studies of the infrared spectral data (Carter and Poulet, 2013; Christensen et al., 2005; Wray et al., 2013), new meteorite discoveries (Agee et al., 2013; Humayun et al., 2013), recent analyses by the Mars Science Laboratory mission (Stolper et al., 2013; Sautter et al., 2014), and re-interpretation of Pathfinder analyses (Foley et al., 2003) have also highlighted the presence of alkaline rocks, silicic rocks, and anorthosites. These occurrences indicate that the martian crust exhibits a larger compositional vari-

\footnotetext{
* Corresponding author at: Massachusetts Institute of Technology, Department of Earth, Atmospheric and Planetary Sciences, 77 Massachusetts Ave (54-1224), Cambridge, MA 02139, USA.

E-mail address: collinet@mit.edu (M. Collinet).
}

ability than initially thought. Part of this variability could result from magmatic differentiation (McSween et al., 2003; Rogers and Nekvasil, 2015), but a better knowledge of the range of potential primary melts is necessary to understand the effects of processes such as fractional crystallization in more detail.

In order to evaluate the extent of compositional variability arising from partial melting of the mantle, we have performed nominally anhydrous experiments over a broad range of pressure $(0.5-2.2 \mathrm{GPa})$ and temperature $\left(1160-1550^{\circ} \mathrm{C}\right)$ on the most widely accepted composition of the primitive martian mantle (Dreibus and Wanke, 1984, 1985). This study extends earlier experiments performed on similar compositions to a larger pressure range (Agee and Draper, 2004; Bertka and Holloway, 1994b) and melting degree (Matsukage et al., 2013), and provides a comprehensive understanding of potential melting products. In particular, low-degree melts, which are of considerable importance to constrain alkaline magmatism on Mars, have not yet been documented.

Our new array of experimental melts enables us to provide new equations to calculate the solidus temperature of the primitive 
Table 1

Model compositions of the primitive martian mantle and starting composition for experiments.

\begin{tabular}{lccccc}
\hline & $\mathrm{DW} 84^{\mathrm{a}}$ & ${\mathrm{LF} 97^{\mathrm{b}}}^{\mathrm{c}}$ & $\mathrm{BF} 97^{\mathrm{c}}$ & $\mathrm{S} \mathrm{99}^{\mathrm{d}}$ & $\mathrm{KC}^{\mathrm{e}}$ \\
\hline $\mathrm{SiO}_{2}$ & 44.4 & 45.4 & 43.7 & 47.5 & 44 \\
$\mathrm{TiO}_{2}$ & 0.14 & 0.14 & - & 0.1 & - \\
$\mathrm{Al}_{2} \mathrm{O}_{3}$ & 3.02 & 2.89 & 3.13 & 2.5 & 2.5 \\
$\mathrm{Cr}_{2} \mathrm{O}_{3}$ & 0.76 & 0.68 & - & 0.7 & - \\
$\mathrm{FeO}$ & 17.9 & 17.2 & 18.7 & 17.7 & 17 \\
$\mathrm{MnO}$ & 0.46 & 0.37 & - & 0.4 & - \\
$\mathrm{MgO}$ & 30.2 & 29.7 & 31.5 & 27.3 & 33 \\
$\mathrm{CaO}$ & 2.45 & 2.35 & 2.49 & 2 & 2.2 \\
$\mathrm{Na}_{2} \mathrm{O}$ & 0.50 & 0.98 & 0.5 & 1.2 & - \\
$\mathrm{K}_{2} \mathrm{O}$ & 0.04 & 0.11 & - & - & - \\
$\mathrm{P}_{2} \mathrm{O}$ & 0.16 & 0.17 & - & - & - \\
$\mathrm{Mg} \#$ & 75.0 & 75.5 & 75.0 & 73.3 & 77.6 \\
$\mathrm{Total}$ & 100.03 & 100.01 & 100.01 & 99.4 & 98.7
\end{tabular}

a Dreibus and Wanke (1984, 1985).

b Lodders and Fegley Jr. (1997).

c Bertka and Fei (1997).

d Sanloup et al. (1999).

e Khan and Connolly (2008).

martian mantle and the melt fraction as a function of pressure and temperature between 0 and $2.5 \mathrm{GPa}$. Improved accuracy on the position of the solidus is critical to reconstruct the geodynamic and thermochemical evolution of Mars (Baratoux et al., 2011; Breuer and Spohn, 2006; Plesa et al., 2014). In addition, the compositions of our experimental melts are compared to crustal martian igneous rocks and serve as a reference for discussing the melting regimes in the mantle and the relative importance of differentiation processes and source heterogeneities. Pressure and temperature conditions of melting are estimated from the natural samples that are similar in composition to the experimental melts. Finally, when the mineralogy and texture of martian rocks are known to some extent, our experimental melt compositions can help determine if they represent silicate liquids, cumulates or rocks affected by secondary alteration.

\section{The primitive mantle of Mars}

Models have been developed to estimate the composition of the bulk silicate portion of Mars (see Taylor, 2013, for a recent review). These models are based on both geochemical (Dreibus and Wanke, 1984, 1985; Lodders and Fegley Jr., 1997; Morgan and Anders, 1979; Sanloup et al., 1999) and geophysical arguments (Khan and Connolly, 2008). They converge towards a single composition that displays key differences from the bulk silicate Earth: lower $\mathrm{Mg \#} \mathrm{(75-78)} \mathrm{and} \mathrm{higher} \mathrm{incompatible} \mathrm{(} \mathrm{Na}, \mathrm{K}, \mathrm{P}$ ) and compatible $(\mathrm{Cr}, \mathrm{Mn})$ volatile elements (Table 1$)$. This composition represents the primitive mantle of Mars (hereafter referred to as PMM) unaffected by magmatic processes such as magma ocean fractional crystallization and crust formation.

We selected the composition from the model of Dreibus and Wanke (1984) for a number of reasons: (1) it is based on comparisons between shergottites and CI chondrites with carefully chosen ratios of elements that behave similarly in magmatic systems; (2) of all the geochemical models, it is the closest to the physically constrained composition of Khan and Connolly (2008); (3) while enriched in volatile elements relative to the bulk silicate Earth, it is characterized by less extreme alkali contents than other models (Lodders and Fegley Jr., 1997; Sanloup et al., 1999) and provides a composition of the primitive mantle after the potential syn-accretion volatile depletion (Albarede, 2009; Halliday and Porcelli, 2001); (4) it is similar to compositions used for earlier experimental studies of the melting of the martian mantle (Agee and Draper, 2004; Bertka and Holloway, 1994a, 1994b; Matsukage et al., 2013), allowing direct comparisons.

\section{Experimental and analytical methods}

\subsection{Starting material and experimental conditions}

The starting material was synthesized from dried high purity oxides $\left(\mathrm{SiO}_{2}, \mathrm{TiO}_{2}, \mathrm{Al}_{2} \mathrm{O}_{3}, \mathrm{Cr}_{2} \mathrm{O}_{3}, \mathrm{Fe}_{2} \mathrm{O}_{3}, \mathrm{MnO}, \mathrm{MgO}\right)$ and preconditioned silicate mixes $\left(\mathrm{CaSiO}_{3}, \mathrm{NaAlSi}_{3} \mathrm{O}_{8}, \mathrm{KAlSi}_{3} \mathrm{O}_{8}, \mathrm{Fe}_{2} \mathrm{SiO}_{4}\right)$. $\mathrm{Fe}$ was added as $\mathrm{Fe}_{2} \mathrm{SiO}_{4}$ and $\mathrm{Fe}_{2} \mathrm{O}_{3}\left(0.2 \mathrm{~mol} \%\right.$ of $\left.\mathrm{Fe}^{3+}\right)$. The amount of $\mathrm{Fe}^{3+}$ was set to match the speciation of $\mathrm{Fe}$ in a melt between the redox buffers CCO and IW under the experimental conditions (Holloway et al., 1992; Médard et al., 2008).

Series of 5 to 8 experiments were conducted at each pressure from 0.5 to $2.0 \mathrm{GPa}$ in $0.5 \mathrm{GPa}$ increments and two additional experiments were performed at $2.2 \mathrm{GPa}$. This pressure range corresponds to a depth of 50 to $200 \mathrm{~km}$ in the planet's interior. Experiments were performed in piston cylinder apparatus at the "Laboratoire Magmas et Volcans" (LMV) in Clermont-Ferrand and at the Massachusetts Institute of Technology (MIT). The experimental temperature $\left(1160-1550^{\circ} \mathrm{C}\right.$ ) was measured close to the hotspot with type C (LMV) and D (MIT) thermocouples and kept constant during the duration of the experiment (24-96 h). The temperature reproducibility was monitored to be within $\pm 10^{\circ} \mathrm{C}$.

A mass of $8-15 \mathrm{mg}$ of the starting material was introduced into a graphite capsule inside a platinum outer capsule, and dried at $400{ }^{\circ} \mathrm{C}$ for $12 \mathrm{~h}$ before being welded shut to ensure nearanhydrous conditions. The water content is thought to not exceed 0.02-0.05 wt.\% from past experiments using similar drying procedures (Laporte et al., 2004; Médard et al., 2008), equivalent to the water content of the martian mantle estimated from apatite compositions (McCubbin et al., 2012). At LMV, experiments were conducted in end-loaded $12.7 \mathrm{~mm}$ (2 GPa) and non-end-loaded $19.1 \mathrm{~mm}(<2 \mathrm{GPa})$ pressure vessels. The experimental assembly was composed of crushable MgO spacers, an inner Pyrex sleeve, a graphite furnace, an outer Pyrex sleeve and a $\mathrm{NaCl}$ cell wrapped in lead foil. Such an assembly has very low friction: calibration of the $19.1 \mathrm{~mm}$ assembly against the melting point of salt resulted in a negligible correction (maximum 3\%), whereas the $12.7 \mathrm{~mm}$ assembly has a friction correction $\leq 5 \%$, as determined from the quartz-coesite transition. At MIT, $12.7 \mathrm{~mm}$ vessels were used, a $\mathrm{BaCO}_{3}$ cell replaced the salt cell as pressure medium and the experimental assembly did not contain Pyrex. This assembly has been found to have no friction correction through calibration against the reaction kushiroite $=$ anorthite + gehlenite + corundum (Hays, 1966). Pressures are thought to be accurate to within $\pm 0.05 \mathrm{GPa}$.

Obtaining a glass that represents the equilibrium liquid is nontrivial for experiments at low degrees of melting. During quench, crystal growth modifies the composition of melts preserved in small pockets. Therefore, from 0.5 to $1.5 \mathrm{GPa}$, we used a thin layer of vitreous carbon spheres (Fig. 1A) to isolate some of the liquid from the crystals (Wasylenki et al., 2003). Because vitreous carbon transforms to graphite needles at higher pressure (2.0-2.2 GPa), we optimized the design of graphite capsules to induce micro-cracks in the lid (Fig. 1B) and extract the melt while limiting iron loss to the Pt outer capsule (Laporte et al., 2004). Melt extraction is helped by the small temperature gradient $\left(10^{\circ} \mathrm{C}\right)$ inherent to our experimental design. For both extraction techniques, we oriented the capsule so that the liquid traps were located at the hotspot.

\subsection{Analytical techniques}

Experimental run products were analyzed by electron microprobe, using a Cameca SX-100 at LMV and a JEOL JXA-8200 Superprobe at MIT. A selection of experiments was measured on both microprobes to ensure inter-laboratory consistency and results were found to be identical within analytical errors. At LMV, the beam conditions were set to $15 \mathrm{kV}$ and $15 \mathrm{nA}$ for silicate and 

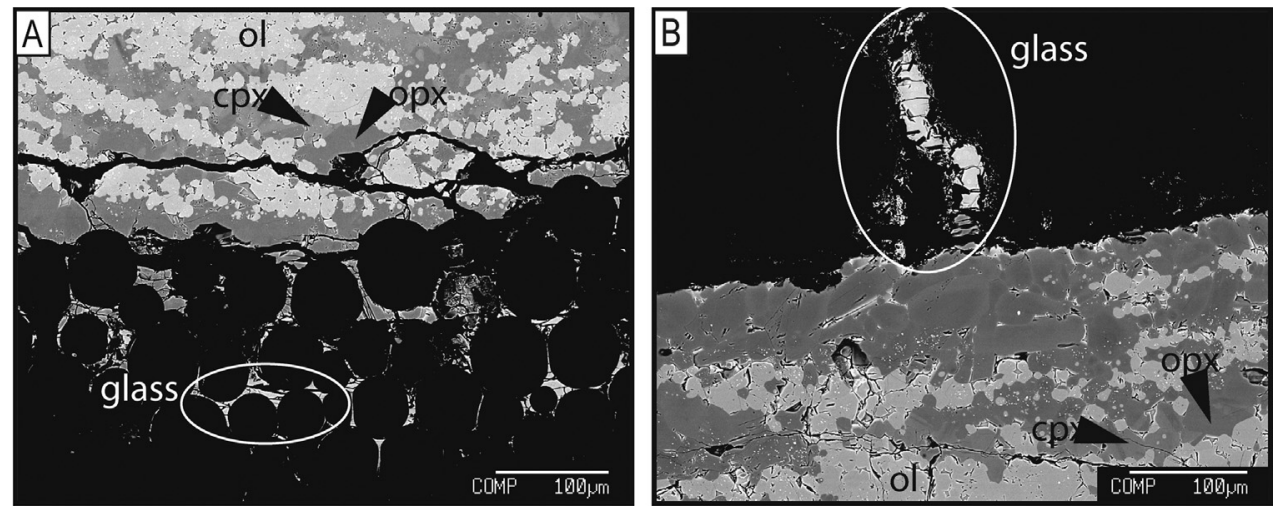

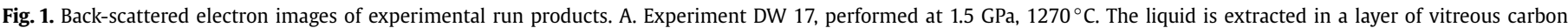
spheres. B. Experiment DW 31, performed at $2 \mathrm{GPa}, 1350^{\circ} \mathrm{C}$. The liquid is extracted into a micro-crack in the lid of the graphite capsule.

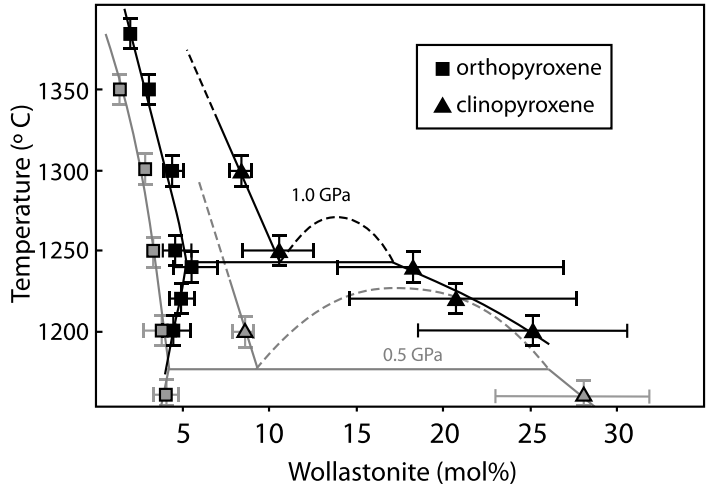

Fig. 2. Composition range of pyroxene at 0.5 and $1.0 \mathrm{GPa}$ and possible evolution of the pyroxene phase diagram. The pigeonite-augite solvus is reduced at $1.0 \mathrm{GPa}$ and becomes metastable at higher pressures. Horizontal bars represent the dispersion of microprobe analyses for each phase. Vertical bars represent the $\pm 10^{\circ} \mathrm{C}$ temperature reproducibility. The central symbol is the average as reported in supplemental Table 2 . The wollastonite content is $\mathrm{Ca} /(\mathrm{Ca}+\mathrm{Fe}+\mathrm{Mg}) \times 100$ in moles.

spinel analyses. For glasses, the intensity was reduced to $8 \mathrm{nA}$ and the beam defocused to $10 \mu \mathrm{m}$ to limit Na loss. Peak and background counting times were $20-40$ s per element, and matrix corrections were performed with the PAP model (Pouchou and Pichoir, 1984). At MIT, a current intensity of $10 \mathrm{nA}$ and a voltage of $15 \mathrm{kV}$ were used for crystals and glasses. To analyze glasses, the beam was defocused to $10 \mu \mathrm{m}$ and $\mathrm{Na}$ was first counted for $5 \mathrm{~s}$. The CITZAF package was used for matrix correction. Analytical standards include well-characterized synthetic and natural glasses and minerals including diopside $(\mathrm{Si}, \mathrm{Ca}, \mathrm{Mg})$, oligoclase $(\mathrm{Na}, \mathrm{Al})$, hematite $(\mathrm{Fe})$, rutile $(\mathrm{Ti})$, chromite $(\mathrm{Cr})$, rhodochrosite $(\mathrm{Mn})$, orthoclase $(\mathrm{K})$ and apatite $(\mathrm{P})$.

Phase proportions in experiments were determined by mass balance calculation from the chemical compositions of the different minerals and the glass. We used the linear regression algorithm LIME (Krawczynski and Olive, 2011), which prevents negative proportions and takes analytical uncertainties into account.

\section{Results}

\subsection{Attainment of equilibrium}

Experimental textures are consistent with equilibrium conditions (Fig. 1A). The grain boundaries are visible even for low degrees of melting (5-10 wt.\%) and highlight the presence of interstitial melt throughout run products, a prerequisite to equilibrate melt traps with crystalline phases. No zoning in ferromagnesian silicates was detected. Only one mineral phase, the sub-calcic augite, exhibits a significant amount of chemical variability (Fig. 2).
Equilibrium between melt and olivine is usually tested by the exchange coefficient between $\mathrm{Fe}$ and $\mathrm{Mg}\left(K_{D}=\right.$ ratio of $\mathrm{Fe} / \mathrm{Mg}$ in olivine over Fe/Mg in the melt). Experimental $K_{D}$ 's are in the range $0.30-0.38$ (Table 2), in good agreement with the model of Toplis (2005) and the classic value of 0.35 generally accepted for martian compositions (Filiberto and Dasgupta, 2011).

Fe loss has been estimated by mass balance calculations using all the elements except Fe. Phase proportions are multiplied by the $\mathrm{FeO}$ content of each phase and the sum is compared to the $\mathrm{FeO}$ content of the starting material. Relative Fe variations compared to the starting material are between $+5 \%$ and $-7 \%$, within uncertainties of the mass-balance calculations.

The final test for equilibrium is based on the quality of mass balance calculations performed from all the elements (including $\mathrm{Fe})$. The sum of squared residuals is low in most cases $(<0.3)$ and can reach slightly higher values (up to 1.3 ) for low-degree melts or when the melt formed dendrites during the quench. Overall, the combination of those tests and the fact that melt compositions and phase proportions form consistent trends (Sections 4.3 and 4.4) indicates that experiments are close to thermodynamic equilibrium.

Graphite capsules set an upper limit to the experimental oxygen fugacity at the CCO buffer (Holloway et al., 1992). The average $\mathrm{fO}_{2}$ of this type of experiment is estimated at CCO $-0.8(\sim \mathrm{IW}+0.5$; Médard et al., 2008). However, redox conditions likely vary slightly (possibly by one log unit) with pressure, temperature and melt fraction. These variations in redox conditions are unlikely to have noticeable effects on phase relations. An important exception could be the stability of Cr-rich spinel, as both $\mathrm{Cr}^{2+}$ and $\mathrm{Cr}^{3+}$ are present under the experimental redox conditions. Since $\mathrm{Cr}^{3+}$ is more compatible in spinel, the stability limit of spinel at high temperature provided in this study is imperfectly constrained and will depend on oxygen fugacity.

\subsection{Phase assemblages}

Just above the solidus, four (1.0-2.2 GPa) to five (0.5 GPa) crystalline phases are in equilibrium with experimental melts. The mineral assembly is composed of olivine, orthopyroxene, sub-calcic augite, spinel and plagioclase at $0.5 \mathrm{GPa}$. When plagioclase is present, it quickly melts out, and clinopyroxene is the next phase to disappear. At 0.5 and $1.0 \mathrm{GPa}$, orthopyroxene coexists with subcalcic augite at low temperature and with pigeonite at higher temperature, highlighting the presence of a pigeonite-augite solvus (Fig. 2). Eventually, pigeonite melts out as the melt fraction increases to around 20 wt.\%. At $1.5-2.2 \mathrm{GPa}$, sub-calcic augite is completely consumed after $10-15$ wt.\% melting and pigeonite is no longer stable. Spinel is the next phase to melt out from the residue when the melt fraction reaches about 25 wt.\%. At higher 
Table 2

Experimental melt compositions.

\begin{tabular}{|c|c|c|c|c|c|c|c|c|c|c|c|c|c|c|c|c|c|}
\hline Exp \# & $T$ & $P$ & $n$ & $\mathrm{SiO}_{2}$ & $\mathrm{TiO}_{2}$ & $\mathrm{Al}_{2} \mathrm{O}_{3}$ & $\mathrm{Cr}_{2} \mathrm{O}_{3}$ & $\mathrm{FeO}$ & $\mathrm{MnO}$ & MgO & $\mathrm{CaO}$ & $\mathrm{Na}_{2} \mathrm{O}$ & $\mathrm{K}_{2} \mathrm{O}$ & $\mathrm{P}_{2} \mathrm{O}_{5}$ & Sum & $K_{D}$ & $\begin{array}{l}K_{D} \\
(\mathrm{~T}) \\
\end{array}$ \\
\hline DW35 & 1350 & 0.5 & 6 & $50.3(4)$ & $0.30(4)$ & 7.9 (2) & $0.80(5)$ & $17.1(1)$ & $0.53(2)$ & $14.8(3)$ & $6.16(9)$ & $1.53(9)$ & $0.15(1)$ & $0.41(7)$ & 99.5 & 0.37 & 0.34 \\
\hline DW27 & 1300 & & 13 & $51.4(5)$ & $0.39(6)$ & $9.7(2)$ & $0.58(7)$ & $15.7(2)$ & $0.46(5)$ & $11.6(4)$ & $7.4(3)$ & $2.0(3)$ & $0.24(3)$ & $0.47(8)$ & 99.1 & 0.35 & 0.34 \\
\hline DW26 & 1250 & & 15 & $52.3(3)$ & 0.49 (5) & $11.9(2)$ & $0.27(5)$ & 13.7 (3) & $0.37(4)$ & $8.9(2)$ & $8.0(2)$ & $3.1(2)$ & $0.27(4)$ & $0.61(8)$ & 98.9 & 0.33 & 0.33 \\
\hline DW28 & 1200 & & 14 & $54.6(9)$ & $0.57(6)$ & $14.5(7)$ & $0.11(4)$ & $10.0(1.0)$ & $0.26(7)$ & $6.2(7)$ & $8.1(3)$ & $4.3(3)$ & $0.46(7)$ & $0.92(23)$ & 98.6 & 0.33 & 0.32 \\
\hline DW34 & 1160 & & 7 & $59.0(8)$ & $0.73(4)$ & $15.1(2)$ & $0.03(3)$ & $7.3(4)$ & $0.21(3)$ & 3.93 (12) & $5.6(3)$ & $5.7(2)$ & $1.0(1)$ & $1.2(2)$ & 100.3 & 0.30 & 0.35 \\
\hline DW16 & 1450 & 1.0 & 6 & $48.9(1.0)$ & $0.25(8)$ & $5.5(3)$ & $1.0(1)$ & $20.1(4)$ & $0.58(4)$ & $17.2(1.6)$ & $5.0(4)$ & $0.98(6)$ & $0.11(4)$ & $0.31(5)$ & 99.5 & 0.30 & 0.34 \\
\hline DW09 & 1385 & & 7 & $49.7(3)$ & $0.35(6)$ & $8.36(8)$ & $0.69(6)$ & $17.8(2)$ & $0.47(7)$ & $13.64(16)$ & 6.9 (1) & $1.50(7)$ & $0.19(2)$ & $0.42(5)$ & 99.0 & 0.35 & 0.35 \\
\hline DW03 & 1350 & & 8 & $49.4(2)$ & $0.45(4)$ & 9.98 (6) & $0.40(4)$ & $16.8(2)$ & $0.45(3)$ & $11.64(8)$ & $8.0(1)$ & $2.05(9)$ & $0.17(2)$ & $0.54(4)$ & 98.9 & 0.35 & 0.34 \\
\hline DW02 & 1300 & & 8 & $52.5(6)$ & $0.45(7)$ & 12.0 & $0.24(8)$ & $13.2(3)$ & $0.37(4)$ & $8.64(10)$ & $8.93(10)$ & $2.79(8)$ & $0.26(6)$ & $0.61(9)$ & 99.0 & 0.35 & 0.35 \\
\hline DW01 & 1250 & & 10 & $52.3(4)$ & $0.57(5)$ & $14.4(3)$ & $0.09(4)$ & $11.5(2)$ & $0.31(6)$ & $6.9(2)$ & $8.2(2)$ & $4.4(3)$ & $0.44(4)$ & $0.88(6)$ & 99.3 & 0.33 & 0.32 \\
\hline B1330 & 1240 & & 6 & $52.1(5)$ & $0.62(4)$ & $16.3(2)$ & $0.08(4)$ & 10.1 (3) & $0.31(2)$ & 5.69 (15) & $8.00(15)$ & $5.25(16)$ & $0.53(3)$ & $0.98(9)$ & 99.0 & 0.30 & 0.31 \\
\hline DW07 & 1220 & & 8 & $53.0(5)$ & $0.70(2)$ & 15.9 (2) & $0.07(2)$ & $9.4(1)$ & $0.28(4)$ & 6.19 (9) & 7.47 (13) & $4.67(12)$ & $0.75(3)$ & $1.55(18)$ & 99.1 & 0.38 & 0.32 \\
\hline DW18 & 1200 & & 5 & $53.2(7)$ & $0.67(4)$ & 17.02 & $0.04(1)$ & $8.8(3)$ & $0.23(3)$ & $5.3(3)$ & $6.3(2)$ & $5.73(10)$ & $0.95(10)$ & $1.72(3)$ & 99.5 & 0.36 & 0.31 \\
\hline DW $33^{\mathrm{a}}$ & 1450 & 1.5 & 8 & $47.6(3)$ & $0.24(3)$ & $5.9(2)$ & $0.86(5)$ & $20.1(2)$ & $0.62(2)$ & $18.1(7)$ & $5.1(3)$ & $1.17(10)$ & $0.10(1)$ & $0.23(4)$ & 99.4 & 0.34 & 0.34 \\
\hline DW04 & 1400 & & 18 & $47.8(7)$ & $0.37(3)$ & $8.4(4)$ & $0.63(9)$ & $19.3(7)$ & $0.53(10)$ & 14.0 & $6.9(5)$ & $1.5(5)$ & $0.20(7)$ & $0.46(9)$ & 99.5 & 0.35 & 0.34 \\
\hline DW14 & 1350 & & 5 & $47.4(2)$ & $0.56(2)$ & 10.27 & $0.34(1)$ & $17.1(3)$ & $0.43(3)$ & $11.35(5)$ & 8.85 (10) & $2.39(5)$ & $0.32(2)$ & $0.75(12)$ & 98.7 & 0.34 & 0.33 \\
\hline DW10 & 1300 & & 8 & $47.4(1.0)$ & $0.76(8)$ & 12.8 (3) & $0.16(4)$ & $14.7(2)$ & 0.39 (3) & $9.12(12)$ & $8.75(11)$ & $4.2(2)$ & $0.51(4)$ & $1.18(10)$ & 98.8 & 0.34 & 0.32 \\
\hline DW17 & 1270 & & 5 & $47.1(4)$ & $0.94(6)$ & $14.56(13)$ & $0.08(3)$ & 13.7 (3) & $0.35(4)$ & $7.8(4)$ & $7.6(1)$ & $5.06(9)$ & $0.90(5)$ & $2.0(2)$ & 99.0 & 0.33 & 0.31 \\
\hline DW25 & 1550 & 2.0 & 20 & $47.4(3)$ & $0.27(6)$ & $5.8(2)$ & $0.86(7)$ & $20.0(4)$ & $0.53(5)$ & $18.6(3)$ & $5.0(2)$ & $1.1(3)$ & $0.13(4)$ & $0.30(6)$ & 99.1 & 0.35 & 0.35 \\
\hline DW23a & 1500 & & 12 & $47.1(5)$ & $0.33(2)$ & 6.9 (3) & $0.74(6)$ & $20.2(7)$ & $0.51(8)$ & $16.4(8)$ & $5.8(4)$ & $1.4(3)$ & $0.15(2)$ & $0.40(5)$ & 98.5 & 0.34 & 0.35 \\
\hline DW20 & 1450 & & 9 & $45.9(6)$ & $0.45(2)$ & 8.5 (3) & $0.53(8)$ & $19.4(2)$ & $0.52(4)$ & $14.4(5)$ & $7.7(2)$ & $1.8(2)$ & $0.22(4)$ & $0.57(6)$ & 99.7 & 0.35 & 0.34 \\
\hline DW29 & 1375 & & 8 & $46.4(7)$ & $0.77(4)$ & $10.8(1)$ & $0.27(5)$ & $16.6(3)$ & $0.43(3)$ & $10.8(1)$ & $8.7(2)$ & $3.61(15)$ & $0.48(3)$ & $1.2(1)$ & 98.2 & 0.35 & 0.33 \\
\hline DW31 & 1350 & & 8 & $45.2(8)$ & $0.99(2)$ & $11.6(3)$ & $0.20(2)$ & $16.8(2)$ & 0.49 (3) & $10.1(3)$ & $8.19(8)$ & $4.0(2)$ & $0.72(3)$ & $1.63(9)$ & 99.9 & 0.34 & 0.32 \\
\hline C556 & 1400 & 2.2 & 3 & $44.5(6)$ & $0.63(5)$ & $10.5(3)$ & $0.24(2)$ & $17.9(2)$ & $0.52(3)$ & 11.7 (6) & $8.8(2)$ & $3.20(7)$ & $0.44(2)$ & $1.48(4)$ & 99.9 & 0.34 & 0.33 \\
\hline C547 & 1350 & & 4 & $43.7(1.0)$ & $1.1(2)$ & 11.1 (3) & $0.14(4)$ & 16. (3) & $0.46(2)$ & $10.6(6)$ & $8.2(2)$ & $4.1(4)$ & $0.96(3)$ & $2.8(1)$ & 98.7 & 0.36 & 0.32 \\
\hline
\end{tabular}

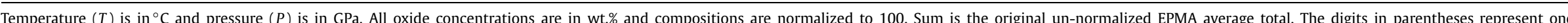

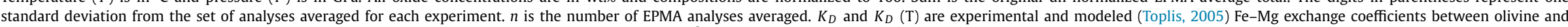
melt. $K_{D}$ 's are calculated with the assumptions that experimental melts are anhydrous and have a $\mathrm{Fe}^{3+} / \mathrm{Fe}^{\mathrm{tot}}$ ratio of 0.02 .

a Liquids analyzed as a mix of glass and quench dendrites. 
temperature, orthopyroxene and olivine compose the residual mineral assembly.

\subsection{Mineral compositions}

Mineral compositions evolve with pressure and temperature (Supplemental Table 2). The CaO content of the clinopyroxene decreases as the temperature increases. At 0.5 and $1.0 \mathrm{GPa}$, it drops from 12 wt.\% (sub-calcic augite) to 4 wt.\% (pigeonite). The Mg\# of olivine and orthopyroxene also evolve with temperature. The Mg\# continuously increases from 74 (olivine) and 77 (orthopyroxene) at low temperature (5 wt.\% of melt) to $83-85$ at high temperature (50\% of melt). Orthopyroxene and sub-calcic augite are richer in $\mathrm{Al}_{2} \mathrm{O}_{3}$ closer to the solidus and at higher pressure. Finally, the $\mathrm{Al}_{2} \mathrm{O}_{3}$ content of spinel decreases with temperature while the $\mathrm{Cr}_{2} \mathrm{O}_{3}$ content increases.

\subsection{Melt compositions}

Experimental melt compositions are strongly dependent on pressure at low degrees of melting. They vary from basanite (2.2 GPa), to nepheline normative hawaiite (1.5 GPa), to mugearite (1.0 GPa), and benmoreite ( $0.5 \mathrm{GPa})$ but converge in the field of basalts for higher degrees of melting (Fig. 4). The silica content decreases with increasing pressure from $59.0 \mathrm{wt} . \%$ at $0.5 \mathrm{GPa}$ to 43.7 wt.\% at $2.2 \mathrm{GPa}$ for the near-solidus experiments (Fig. 5, Table 2). $\mathrm{SiO}_{2}$ decreases with increasing degree of melting at low pressure (0.5-1.0 GPa) and slightly increases with increasing degree of melting at high pressure (2.0-2.2 GPa). The $\mathrm{Al}_{2} \mathrm{O}_{3}$ content decreases with increasing temperature at all pressures but is higher in the lower-pressure melts. However, at $0.5 \mathrm{GPa}$ and low temperature, the melt is in equilibrium with plagioclase and contains less $\mathrm{Al}_{2} \mathrm{O}_{3}$ than melts in experiments at $1.0 \mathrm{GPa}$. $\mathrm{FeO}, \mathrm{MgO}$ and $\mathrm{MnO}$ are more abundant at high pressure and increase with increasing temperature. $\mathrm{CaO}$ behaves as a compatible component and increases in the melt as the melting progresses. $\mathrm{CaO}$ reaches a maximum before clinopyroxene disappears and is progressively diluted afterwards. The alkalis are incompatible in residual minerals and decrease with increasing degree of melting. They are slightly more abundant in low-pressure melts as the compatibility of $\mathrm{Na}$ in pyroxene is higher at high pressure. Conversely, while titanium and phosphorus are also incompatible, they are more abundant in high-pressure melts. The low $\mathrm{P}_{2} \mathrm{O}_{5}$ content of low-pressure liquids reflects a higher compatibility of phosphorus in olivine at low pressure. Distribution coefficients for $\mathrm{P}$ between olivine and melt decrease from 0.045 at $1.0 \mathrm{GPa}$ (DW18) to 0.018 at $2.2 \mathrm{GPa}$ (C547). $\mathrm{Cr}_{2} \mathrm{O}_{3}$ is compatible and increases in the melt with increasing degree of melting. At low temperature, high-pressure melts are slightly enriched in $\mathrm{Cr}_{2} \mathrm{O}_{3}$ compared to low-pressure melts which are close to the detection limit of EPMA analysis.

Water contamination cannot be entirely avoided in nominally anhydrous experiments (e.g. Laporte et al., 2004; Médard et al., 2008). Water contents were not directly measured in our experimental glasses. However, the totals of EPMA analyses are close to 100 wt.\% (Table 2) and are uncorrelated to the melt fractions. This is consistent with small amounts of $\mathrm{H}_{2} \mathrm{O}$, not exceeding the contamination expected from previous experiments using the same drying procedure. The average total of analyses performed on the 7 low-degree melts (<10 wt.\% of melt) is 99.3 wt.\% and suggest that the total amount of dissolved volatiles is $<1 \mathrm{wt} . \%$. A maximum value of $0.02-0.05$ wt.\% $\mathrm{H}_{2} \mathrm{O}$ in the bulk (Laporte et al., 2004; Médard et al., 2008) would translate to a maximum of $0.5-1.0$ wt.\% $\mathrm{H}_{2} \mathrm{O}$ in the lowest degree melts. In addition to water contamination, the dissolution of a small amount of carbon is ubiquitous in experiments in equilibrium with graphite. The maximum amount of $\mathrm{CO}_{2}$ expected in our experiments would be in the range
0.05-0.2 wt.\% $\mathrm{CO}_{2}$ in the melt if most $\mathrm{Fe}^{3+}$ is reduced and the $\mathrm{fO}_{2}$ reached the CCO buffer (Holloway et al., 1992).

Projection diagrams (Fig. 6) from calculated mineral components (Grove, 1993) highlight the pressure effect on the composition of melts. Melts move away from the quartz apex and towards the olivine and clinopyroxene apices with increasing pressure. As the degree of melting increases, melts get closer to the clinopyroxene apex until clinopyroxene disappears from the melting residue. With only orthopyroxene and olivine being consumed, melts then move towards the olivine-quartz join. Finally, melts are aligned with the bulk composition and the olivine apex when orthopyroxene melts out.

Melt compositions are in good agreement with experiments from Bertka and Holloway (1994b). However, their lower temperature experiment is $\sim 2 \mathrm{wt}$.\% poorer in $\mathrm{SiO}_{2}$. This is likely due to the omission of key minor elements $(\mathrm{K}, \mathrm{P}, \mathrm{Mn}, \mathrm{Cr})$ in their starting material but could also reflect a lower $\mathrm{H}_{2} \mathrm{O}$ contamination (Supplemental Fig. 2). Experiments from Matsukage et al. (2013) are anomalous compared to our experiments and those from Bertka and Holloway (1994b). In particular, we believe that the composition of 1.0 GPa melts by Matsukage et al. (2013) is affected by quench modifications as shown by the low olivine/melt $-\mathrm{Fe} / \mathrm{Mg}$ $K_{D}$ 's (0.21-0.25 instead of $\sim 0.35$ in this study). Note that the thermodynamic calculator pMELTS considerably underestimates $\mathrm{SiO}_{2}$ contents and overestimate $\mathrm{FeO}$ contents of our melts ( 5 wt.\% offsets; Supplemental Fig. 4). Similar shortcomings have also been observed for terrestrial compositions (e.g. Gaetani, 1998).

\subsection{Melting behavior}

The proportions of residual mineral phases are dependent on the degree of melting (or the temperature) and the pressure (Fig. 7). At 0.5-1.0 GPa and low temperature, the olivine proportion first increases with increasing degree of melting while the proportions of pyroxene and spinel diminish. The relative proportions of clinopyroxene and orthopyroxene evolve in a complex manner. The amount of sub-calcic augite slightly increases while its wollastonite content drops. As a result, the $\mathrm{CaO}$ content of the liquid increases with temperature despite the increase of the clinopyroxene fraction. Eventually, sub-calcic augite transforms into pigeonite when the solvus is reached (Fig. 2) and the proportion of clinopyroxene falls off rapidly at higher temperature.

A melting reaction can be calculated if we approximate the clinopyroxene fraction to decrease linearly with increasing temperature. The following expression represents a peritectic melting reaction and is valid at 0.5 and $1.0 \mathrm{GPa}$ :

$$
\begin{aligned}
0.47 & ( \pm 0.15) \text { orthopyroxene }+0.80( \pm 0.20) \text { clinopyroxene } \\
& +0.08( \pm 0.03) \text { spinel }=0.35( \pm 0.10) \text { olivine }+1.00 \text { melt }
\end{aligned}
$$

Above $1.0 \mathrm{GPa}$, olivine is a reactant and orthopyroxene is produced as long as clinopyroxene is present. In addition, the augite-pigeonite solvus likely becomes metastable and/or subcalcic augite disappears before the solvus can be reached. The melting reactions can thus be approximated by peritectic reactions producing orthopyroxene instead of olivine at $1.5 \mathrm{GPa}$ :

$$
\begin{aligned}
& 1.60( \pm 0.3) \text { clinopyroxene }+0.22( \pm 0.05) \text { olivine } \\
& +0.08( \pm 0.03) \text { spinel } \\
& =0.90( \pm 0.20) \text { orthopyroxene }+1.00 \text { melt } \\
& \text { and at } 2.0 \mathrm{GPa} \text { : } \\
& 2.10( \pm 0.30) \text { clinopyroxene }+0.23( \pm 0.05) \text { olivine } \\
& +0.17( \pm 0.06) \text { spinel } \\
& =1.50( \pm 0.30) \text { orthopyroxene }+1.00 \text { melt }
\end{aligned}
$$




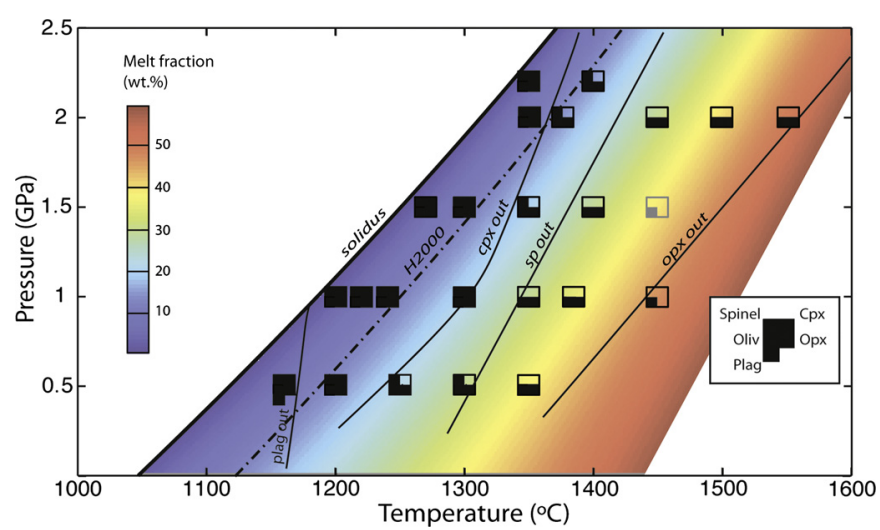

Fig. 3. Phase diagram based on experimental results. Solid lines represent the solidus and phase boundaries. The dot-dash line is the solidus for terrestrial peridotite (Hirschmann, 2000). Melt fractions are calculated by linear regression. Experiment DW 33 (in grey, $1450^{\circ} \mathrm{C}-1.5 \mathrm{GPa}$ ) was equilibrated at a higher temperature $\left(\sim 1500^{\circ} \mathrm{C}\right)$ than the nominal temperature as suggested by its high $\mathrm{MgO}$ content.

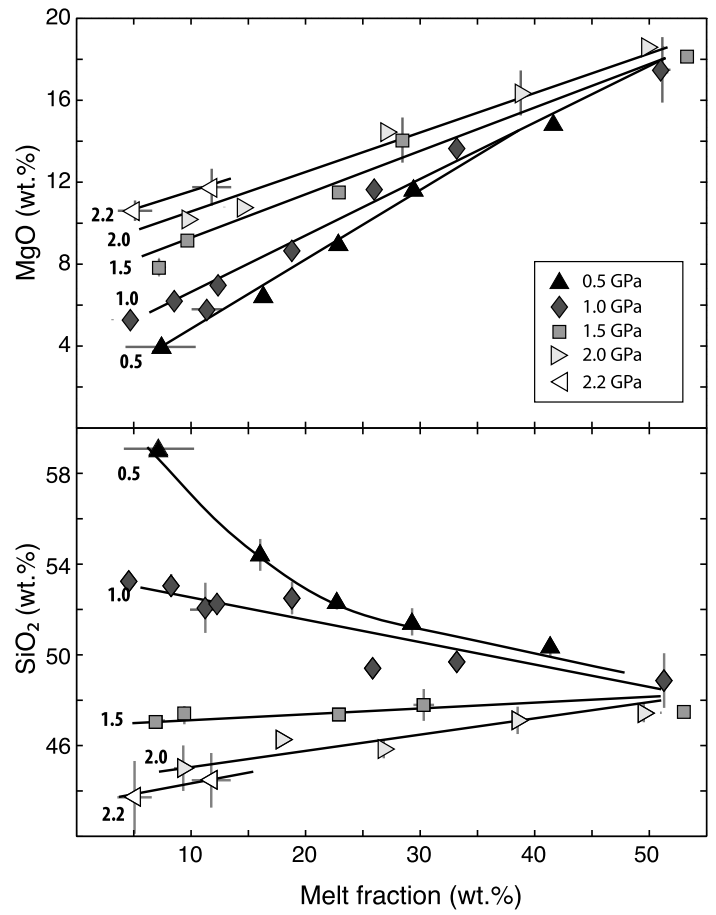

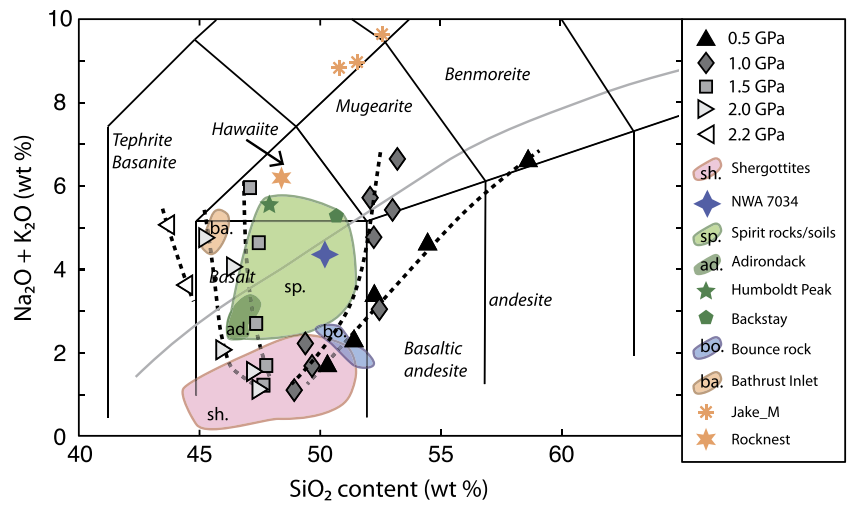

Fig. 4. Total Alkali-Silica (TAS) diagram comparing experimental melts with martian rocks. Modified from Stolper et al. (2013) and Schmidt et al. (2014). The solid grey line separates alkaline (up) and sub-alkaline (down) fields. Dotted lines are visual aids illustrating the compositional trends at each pressure.

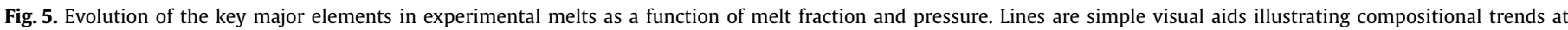
each pressure. Vertical and horizontal bars represent one standard deviation uncertainties.

Following the disappearance of clinopyroxene, melting reactions turn into eutectic reactions that can be expressed by a single equation, which is insensitive to pressure:

\section{$0.70( \pm 0.15)$ orthopyroxene $+0.30( \pm 0.08)$ olivine $=1.0$ melt}

The experimental pressure and temperature have a considerable effect on the composition of silicate melts coexisting with olivine, orthopyroxene and clinopyroxene. The silica activity of the liquid drops with pressure while the activities of $\mathrm{MgO}$ and $\mathrm{FeO}$ increase (Supplemental Fig. 1; Sack and Ghiorso, 1989; Hirschmann et al., 1998). Accordingly, the liquid in equilibrium with martian peridotites becomes enriched in olivine component as the pressure increases. Minor elements such as $\mathrm{K}$, Na and $\mathrm{H}$ can also influence major elements concentrations by changing the melt structure and activity coefficients (Gaetani and Grove, 1998; Hirschmann et al., 1998). In particular, the concentration of minor

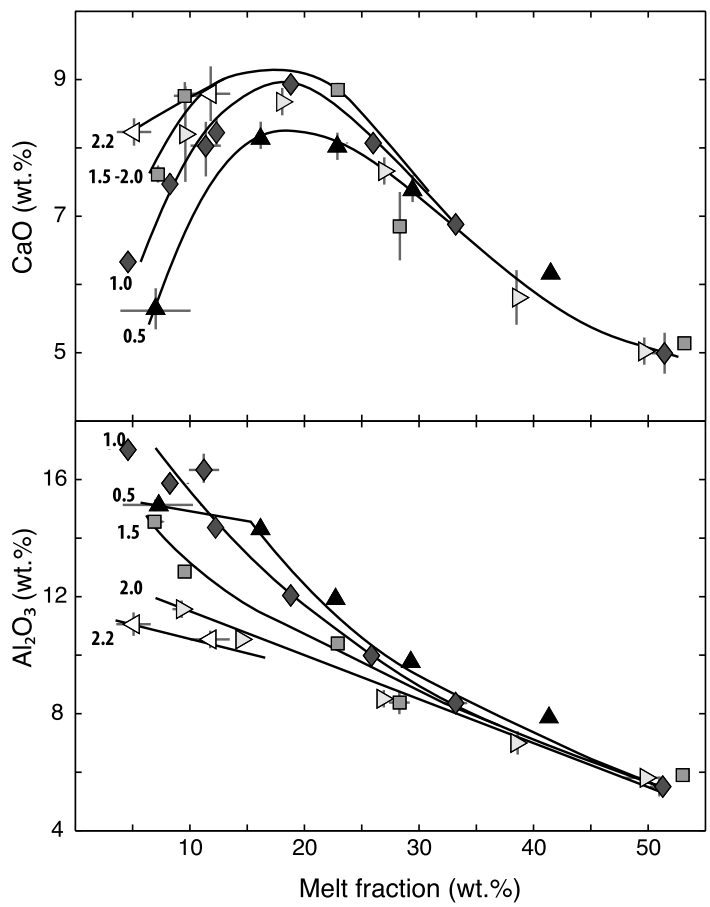

incompatible elements in low-degree melts could contribute to increase the $\mathrm{SiO}_{2}$ contents at low pressure (Supplementary material).

Pressure and temperature conditions also have an effect on the stability of silicates as observed from the phase diagram (Fig. 3). At 2.0-2.2 GPa, the stability field of clinopyroxene is decreased and it melts out faster (10-15 wt.\% of melt) than at lower pressure (20 wt.\% of melt). On the contrary, the stability of orthopyroxene increases, as illustrated by the orthopyroxene-out curve, which enter regions of higher melt fraction at higher pressure.

\section{Discussion}

\subsection{Position of the solidus}

We use the melt fraction in each experiment, determined by mass-balance calculation, to estimate the position of the solidus of the martian mantle. The solidus temperature at each pressure is 


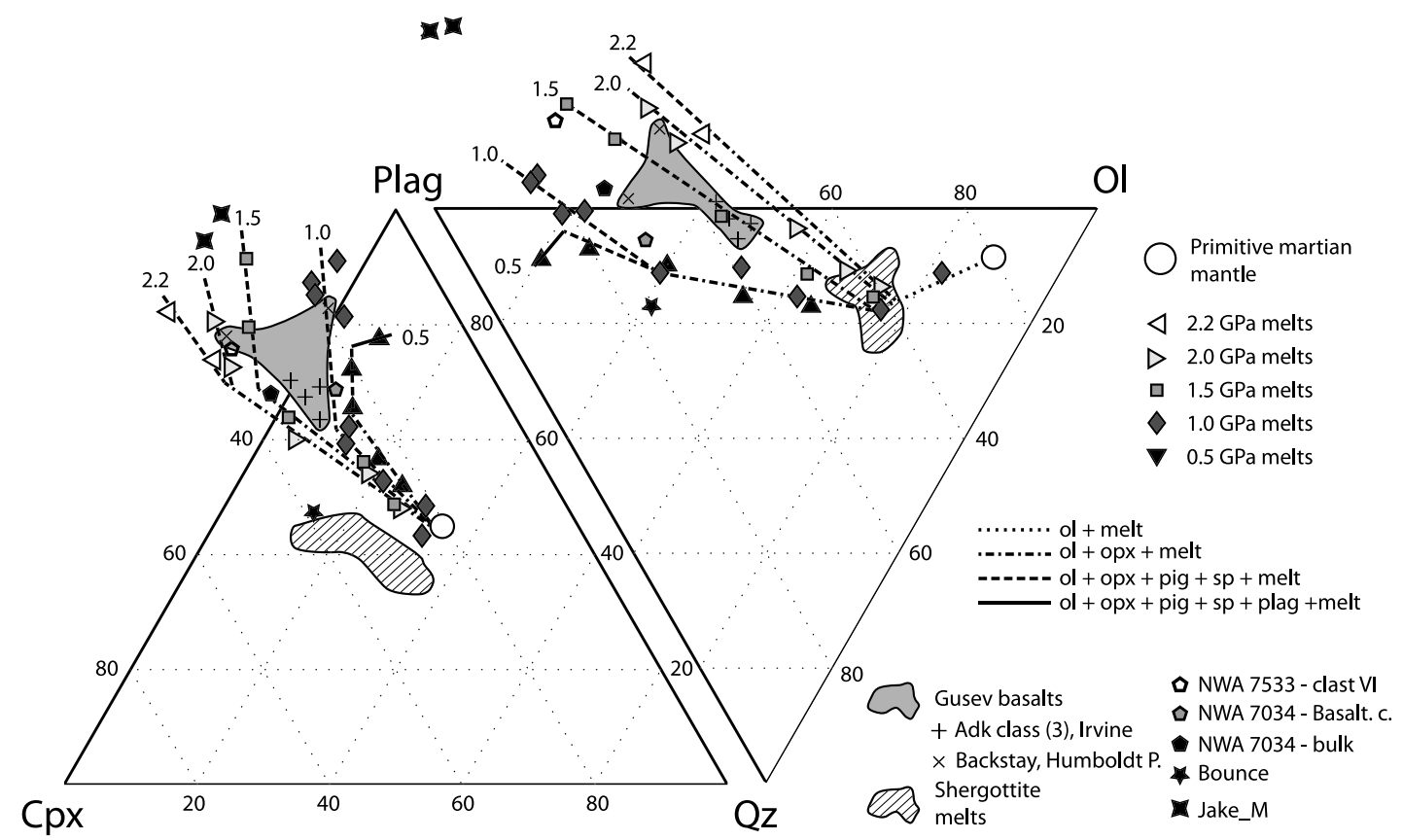

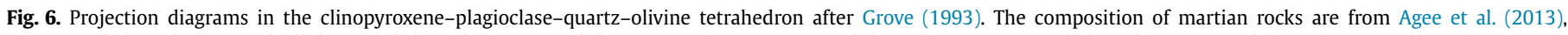

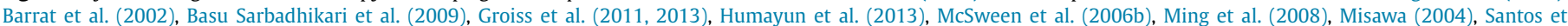
al. (2015), Stolper et al. (2013) and Zipfel et al. (2011).

given by the zero intercept of the melt fraction as a linear function of the temperature. Then, the four solidus temperatures are fitted with first- and second-order polynomial equations. The following linear approximation is sufficient to predict the temperature of the solidus between 0.5 and $2.2 \mathrm{GPa}$, the range of pressure investigated.

$T_{S}\left({ }^{\circ} \mathrm{C}\right)=1054-129.3 P(\mathrm{GPa})$

The martian solidus is $50^{\circ} \mathrm{C}$ lower than the solidus of a terrestrial peridotite over this pressure range (Hirschmann, 2000). This difference likely reflects the lower $\mathrm{Mg \#}$ and higher alkali content of the Dreibus and Wänke (1984) composition. Compared to our results, Bertka and Holloway (1994a) estimated the solidus to be $30^{\circ} \mathrm{C}$ higher on average. This offset might result from the absence of $\mathrm{K}_{2} \mathrm{O}$ in their starting material and the difficulty of observing melt at low temperature without liquid traps.

The pressure and temperature conditions of the solidus of the terrestrial mantle follow a second-order polynomial relationship up to $10 \mathrm{GPa}$ (Hirschmann, 2000). We adjusted the coefficients of our own second-order fit to follow the curve of Hirschmann (2000) and maintain a $\sim 50^{\circ} \mathrm{C}$ offset between martian and terrestrial peridotites up to around $8 \mathrm{GPa}$ (Supplemental Fig. 3):

$T_{S}\left({ }^{\circ} \mathrm{C}\right)=1033+168.1 P(\mathrm{GPa})-14.22 P^{2}(\mathrm{GPa})$

We also performed a second-order polynomial regression of the melt fraction as a function of the pressure and temperature based on a selection of experiments. Experiment DW16 $\left(1.5 \mathrm{GPa}, 1450^{\circ} \mathrm{C}\right)$ is characterized by anomalous $\mathrm{MgO} /$ temperature and melt fraction/temperature ratios relative to the general trend (Fig. 7). It must have equilibrated at a higher temperature $\left(>1500^{\circ} \mathrm{C}\right)$ and was excluded. We obtained the following expression for the melt fraction as a function of the pressure and temperature:

$F=-149.2-56.93 P-2.442 P^{2}+0.1439 T+0.0321 P T$

$F$ is the melt fraction in weight percent; $P$ is the pressure in GPa; $T$ is the temperature in ${ }^{\circ} \mathrm{C}$.

This function is plotted on the $P-T$ phase diagram (Fig. 3) and can be compared to melt proportions in Supplemental Table 1.
We believe that meaningful extrapolations can be performed up to 5 GPa (Supplemental Fig. 3).

\subsection{Comparison with the melting of terrestrial peridotites}

The melting behavior of the PMM and its pressure dependence share key characteristics with the melting of fertile terrestrial peridotites. First, the decrease in $\mathrm{SiO}_{2}$ with increasing pressure has been recognized by O'Hara (1968) and Takahashi and Kushiro (1983) as an important characteristic of peridotite melting. Peritectic reactions characterized by olivine production at low pressure and orthopyroxene production at high pressure are similar to those described by Kinzler and Grove (1992) and Kinzler (1997). However, the transition from olivine-production to orthopyroxeneproduction occurs at lower pressure (1.0-1.5 GPa) for the Fe-rich martian mantle compared to terrestrial compositions ( $\sim 1.9 \mathrm{GPa}$; Kinzler, 1997). Our experiments showcase a $\mathrm{CaO}$ maximum that coincides with clinopyroxene disappearance for a degree of melting of 15 to $20 \mathrm{wt}$.\%, similar to that reported by Baker and Stolper (1994). Compared to the Earth's mantle, the principal difference in phase stability is the presence of pigeonite at a relatively high pressure $(1.0 \mathrm{GPa})$ during partial melting because the pigeoniteaugite solvus is stabilized to lower temperatures. The presence of a pigeonite-subcalcic augite solvus at high pressure and just above the solidus temperature results from the high Fe content of the martian mantle (Bertka and Holloway, 1993). The high $\mathrm{Cr}_{2} \mathrm{O}_{3}$ content of the PMM might also stabilize spinel to higher temperature. For a given degree of melting, martian melts are richer in $\mathrm{FeO}$, $\mathrm{Cr}_{2} \mathrm{O}_{3}$, alkalis and $\mathrm{P}_{2} \mathrm{O}_{5}$ and poorer in $\mathrm{TiO}_{2}, \mathrm{Al}_{2} \mathrm{O}_{3}$ and $\mathrm{CaO}$ compared to their terrestrial equivalents.

\subsection{Comparisons with martian volcanic rocks}

The compositions of a large number of volcanic rocks analyzed in Gusev crater, and several new samples from the collection of martian meteorites, are similar to our experimental melts. Conversely, shergottites and the few volcanic rocks analyzed by the Curiosity rover in Gale crater present significant differences. In the 

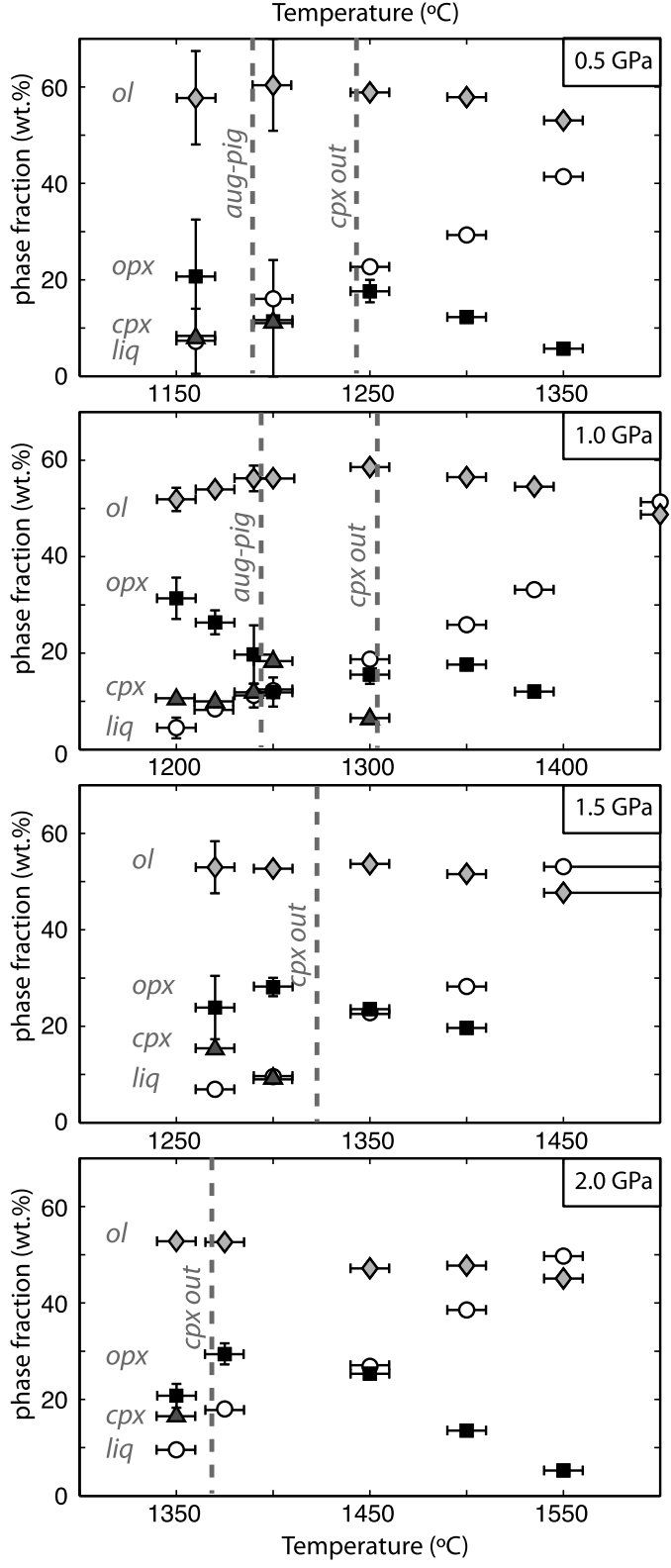

Fig. 7. Evolution of phase proportions with temperature: melts (open circles), clinopyroxene (triangles), orthopyroxene (squares), olivine (diamonds). Spinel is not plotted due to its low proportions ( $<2 \mathrm{wt} . \%$ ). The dashed lines represent the temperatures of sub-calcic augite to pigeonite transition and clinopyroxene disappearance. Vertical error bars are $1 \sigma$ of mass balance calculations. Horizontal error bars are the $\pm 10^{\circ} \mathrm{C}$ uncertainties on experimental temperatures.

following section, we compare these rocks to our experimental melts (Fig. 8) to discuss their origin and crystallization history.

\subsubsection{Gusev plains: Adirondack-class basalts}

The Adirondack-class basalts were rapidly recognized as potential primary basalts derived from the martian mantle given their high $\mathrm{MgO}$ content $(\mathrm{Mg \#}=76.5)$ and abundant olivine phenocrysts (McSween et al., 2006b). The experimental study by Monders et al. (2007) confirmed that the average composition of the Adirondack basalts could represent a primary mantle melt as it is multiply saturated with orthopyroxene and olivine at $1.0 \mathrm{GPa}$ and $1320^{\circ} \mathrm{C}$

Adirondack-class basalts are similar to our experimental melts produced between 1.0 and $2.0 \mathrm{GPa}$ for $15-25 \mathrm{wt} . \%$. This range in melt fraction corresponds to the transition from a lherzolitic to a harzburgitic residue, and Adirondack basalts plot along the junction between orthopyroxene-olivine and clinopyroxene- orthopyroxene-olivine cotectic curves on projection diagrams (Fig. 6). Overall, we observe that the best match with Adirondack basalts is a liquid produced by $25 \mathrm{wt} . \%$ melting $\left(1380^{\circ} \mathrm{C}\right)$ at $1.5 \mathrm{GPa}$ (135 km depth) that crystallized $5 \mathrm{wt} . \%$ of olivine. Monders et al. (2007) proposed source conditions of $1.0 \mathrm{GPa}$ and $1320^{\circ} \mathrm{C}$ from the position of the olivine-orthopyroxene multi-saturation point (MSP) in their experiments. These different conditions of melting result from the higher $\mathrm{FeO} / \mathrm{MgO}$ ratio of Adirondack basalts compared to our experimental melts. The difference between the $\mathrm{FeO} / \mathrm{MgO}$ ratios might reflect a source slightly richer in iron or the fractionation of a small amount of olivine from the parental melt of the Adirondack-class basalts. An addition of 5 wt.\% of olivine to a basaltic composition can move the MSP by up to $0.5 \mathrm{GPa}$ and $90^{\circ} \mathrm{C}$ towards higher pressure and temperature (Médard et al., 2004). Accordingly, the source conditions proposed by Monders et al. (2007) represent lower-pressure/temperature limits, while our experimental conditions $\left(1350-1400^{\circ} \mathrm{C} ; 1.5 \mathrm{GPa}\right)$ likely represent upper-pressure/temperature limits. Our experiments confirm that Adirondack-class basalts are derived from a deep ( 90-135 km) and primitive mantle reservoir.

\subsubsection{Columbia Hills: alkali basalts}

In the Columbia Hills, Spirit analyzed the first alkali basalts on Mars. Irvine, Backstay and Humboldt Peak seem weakly affected by secondary processes and are usually referred to as alkaline volcanic rocks or alkali basalts (McSween et al., 2006a; Ming et al., 2008). They are aphanitic float rocks that likely contain olivine and pyroxene. Columbia Hills rocks share key characteristics with experimental melts produced at low degrees of melting ( 8 to $12 \mathrm{wt} . \%$ ) and plot very close to them on projection diagrams (Fig. 6). However, they are not identical in composition to the experimental melts. The most striking difference is the lower $\mathrm{CaO}$ contents of alkaline rocks compared to our melts (Fig. 8). Significant chemical diversity is also observed among the rocks from the Columbia Hills. Strictly speaking, Irvine is a sub-alkaline basalt that resembles Adirondack-class basalts but is much richer in $\mathrm{K}_{2} \mathrm{O}$, slightly richer in $\mathrm{Na}_{2} \mathrm{O}$ and poorer in $\mathrm{CaO}$ and $\mathrm{Al}_{2} \mathrm{O}_{3}$. Conversely, Backstay contains more $\mathrm{Al}_{2} \mathrm{O}_{3}$ and has a higher $\mathrm{Mg \#} \mathrm{(53.3)} \mathrm{than}$ Adirondack-class basalts (50.1), Irvine (46.2) and Humboldt Peak (49.7).

The lower $\mathrm{CaO}$ content of alkali basalts from Columbia Hills compared to our experimental melts could imply that they are not primary basalts and that their low $\mathrm{CaO}$ content was produced by crystallization of a mineral assemblage containing Ca-rich pyroxene. However, the high variability of their $\mathrm{Al}_{2} \mathrm{O}_{3}$ concentrations (8.5 to 13.5 wt.\%) for a limited range of $\mathrm{MgO}$ contents (8.5 to $9.8 \mathrm{wt} . \%)$ challenges this scenario. Plagioclase must have appeared after different degrees of crystallization to produce residual liquids with variable $\mathrm{Al}_{2} \mathrm{O}_{3}$ contents. Irvine and Backstay are saturated with olivine on the liquidus (e.g. Nekvasil et al., 2009). Therefore, the crystallization of a large amount of plagioclase should be accompanied by significant olivine fractionation, which is inconstant with constant and elevated $\mathrm{MgO}$ contents. Invoking a refractory mantle source to account for the lower $\mathrm{CaO}$ content of Columbia Hills rocks is equally unsatisfactory. Our low-degree melts highlight that mantle sources affected by a previous melting event should be more depleted in $\mathrm{Al}_{2} \mathrm{O}_{3}$ than in $\mathrm{CaO}$ relative to the PMM and could not produce a melt with an $\mathrm{Al}_{2} \mathrm{O}_{3}$ content as high as that of Backstay. In addition, a depleted mantle will start to melt at a higher temperature and, as long as clinopyroxene is present, the $\mathrm{CaO} / \mathrm{MgO}$ ratio is not expected to change significantly. If Humboldt Peak, Irvine and Backstay all represent liquid compositions, a more complex scenario is necessary to account for their low $\mathrm{CaO}$ content and their variable $\mathrm{Al}_{2} \mathrm{O}_{3}$ contents. Mantle reservoirs with distinct $\mathrm{Al}_{2} \mathrm{O}_{3}$ contents but similar $\mathrm{CaO}$ contents in close proximity are expected from the crystallization and overturn of 


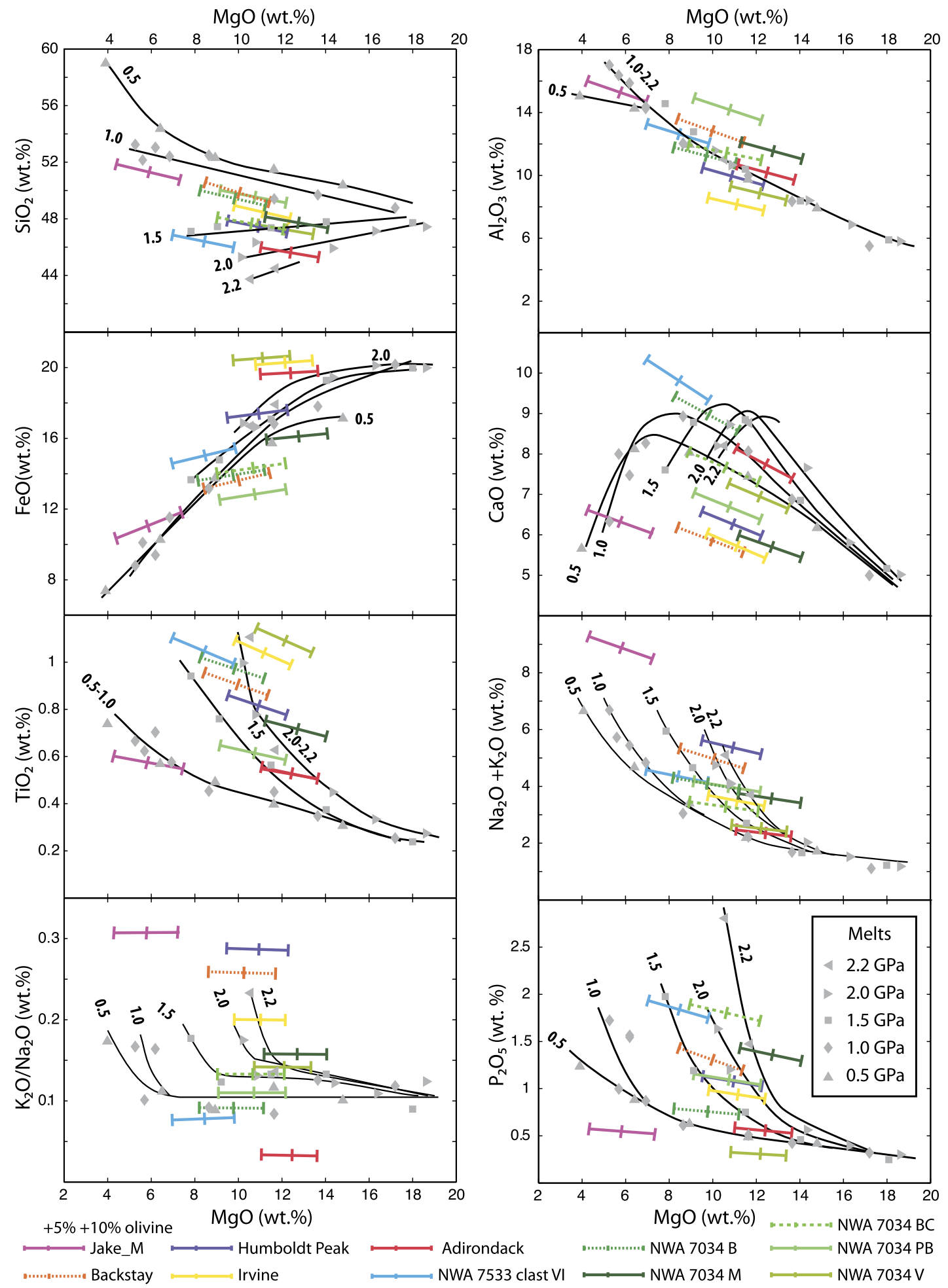

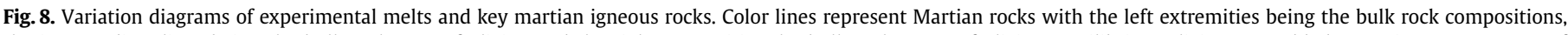

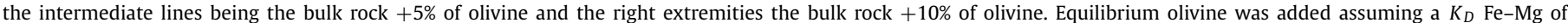

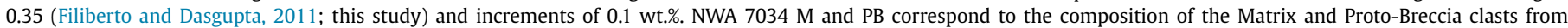

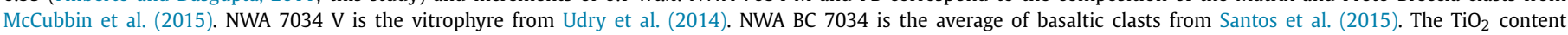

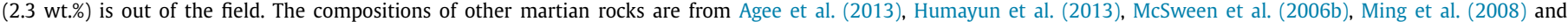
Stolper et al. (2013).

a magma ocean (Debaille et al., 2009; Elkins-Tanton et al., 2005; Scheinberg et al., 2014). Another possibility, which could be related to the former, is that the mantle source of Columbia Hills rocks was re-fertilized by variable amounts of low-degree melts.
Finally, if Columbia Hills rocks represent cumulates rather than liquid compositions, the low $\mathrm{CaO}$ contents could reflect a late (postcumulus) appearance of Ca-rich pyroxenes relative to plagioclase (Francis, 2011). 


\subsubsection{Gale crater: mugearite and other alkaline rocks}

In early 2013, with the first results obtained at Gale crater by Curiosity (Stolper et al., 2013) and the description of a new meteorite type - the regolith breccias 7034/7533 (see next section) - alkaline magmatism was shown to be ubiquitous on Mars and of greater importance than previously thought (McSween et al., 2009). Numerous rocks analyzed at Gale crater displayed extreme contents of alkali elements, particularly potassium. However, only a few samples have been argued to be of volcanic origin. Jake Matijevic (Jake_M), analyzed with both the APXS and ChemCam instruments, was described as the first martian mugearite. It is characterized by low $\mathrm{MgO}$ and $\mathrm{FeO}$ contents and high $\mathrm{Al}_{2} \mathrm{O}_{3}$ and alkali contents, and was interpreted as the product of extensive fractional crystallization of an alkali-basalt based on comparisons with terrestrial analogs (Stolper et al., 2013). Other potential volcanic rocks from Gale crater include the different rock types from the Bradbury Rise locality. These samples were only analyzed with the ChemCam instrument (laser-induced breakdown spectroscopy), and precise bulk rock compositions are not available. However, chemical analyses highlighted an important compositional diversity ranging from basaltic to evolved and alkali-rich compositions similar to Jake_M (Sautter et al., 2014; Schmidt et al., 2014). Alkalibasalts and tholeiitic basalts might coexist in the same locality, as also observed in Gusev Crater.

Jake_M is significantly richer in alkalis compared to our experimental melts and also has a higher $\mathrm{K}_{2} \mathrm{O} / \mathrm{Na}_{2} \mathrm{O}$ ratio. Both of these characteristics might point towards extremely low degrees of melting (2-3 wt.\%). The lowest-degree melts that we were able to measure range between 5 and 8 wt.\% of melting. Thus, experimental trends must be extrapolated in order to discuss the potential origin of Jake_M as a primary melt. Between 0.5 and 1.0 GPa, lower degree melts from the PMM would have lower $\mathrm{FeO}, \mathrm{MgO}$ and $\mathrm{CaO}$ contents compared to Jake_M. On the other hand, higher pressure melts ( $\sim 1.5 \mathrm{GPa})$ would have similar abundances of all the major elements except $\mathrm{SiO}_{2}$, and would also have much higher $\mathrm{P}_{2} \mathrm{O}_{5}$ and $\mathrm{TiO}_{2}$ contents. Jake_M is therefore more likely derived from melts that have undergone fractional crystallization. In order to maintain a high $\mathrm{Al}_{2} \mathrm{O}_{3}$ content, the crystallization should have occurred at depth or in the presence of water, when the appearance of plagioclase is delayed (Stolper et al., 2013). The extreme alkali and $\mathrm{Al}_{2} \mathrm{O}_{3}$ contents of Jake_M are easier to produce from a low degree melt $(\sim 10 \mathrm{wt} . \%)$ produced at a pressure higher than 1.0 GPa. Metasomatism is often invoked to enrich the source of Jake_M in potassium (Schmidt et al., 2014; Stolper et al., 2013). Alternatively, we suggest that low-degree melts, produced from a mantle not anomalously enriched, can fractionate and eventually crystallize to form rocks similar to Jake_M. Experiments performed from the composition of Backstay illustrate how residual liquids rich in $\mathrm{Al}_{2} \mathrm{O}_{3}$ and poor in $\mathrm{MgO}$ can be derived from martian alkali basalts (Nekvasil et al., 2009).

\subsubsection{NWA 7034/7533: martian crust-like meteorites}

The paired meteorites NWA 7034 and 7533 are regolith breccias that have been argued to be more representative of the bulk martian crust than shergottites (Agee et al., 2013). They have a chondritic $\mathrm{CaO} / \mathrm{Al}_{2} \mathrm{O}_{3}$ ratio and are rich in alkali elements. The bulk-rock composition of NWA 7034 (Agee et al., 2013) and the composition of the basaltic clast VI from NWA 7533 (Humayun et al., 2013) are close to our low degree melts (Fig. 8). In particular, unlike alkali basalts from Columbia Hills, they are not depleted in $\mathrm{CaO}$ and have lower $\mathrm{K}_{2} \mathrm{O} / \mathrm{Na}_{2} \mathrm{O}$ ratios. A vitrophyric clast in NWA 7034 is closer in composition to Humphrey (Adirondack-class) and thus to our higher-degree melts (Udry et al., 2014). The average composition of basalt clasts analyzed by Santos et al. (2015) is also within experimental trends with the exception of $\mathrm{TiO}_{2}$, which is more than twice as abundant (2.3 wt.\%). Other components of NWA 7034 exhibit low $\mathrm{CaO} / \mathrm{Al}_{2} \mathrm{O}_{3}(\sim 0.5)$ ratios for relatively high $\mathrm{MgO}$ contents compared to experimental melts (McCubbin et al., 2015). The complex texture of NWA 7034/7533 and the diversity of its components make it difficult to argue that it represents a primitive melt or even a silicate liquid. The two clasts displaying magmatic textures, the basaltic clast (VI) of Humayun et al. (2013) and the vitrophyre of Udry et al. (2014), are impact melts contaminated by a $\mathrm{Cl}$ chondrite as suggested by their high $\mathrm{Ni}$ and Ir contents. However, the chondritic contaminant is unlikely to have disturbed the composition in major elements. If no fractional melting or crystallization were associated with the impact, magmatic clasts could represent the composition of their protoliths. Olivine must be added to the two clasts to bring their $\mathrm{FeO} / \mathrm{MgO}$ ratios closer to those of experimental melts (Fig. 8). When $\sim 8 \mathrm{wt} . \%$ of olivine is added to the composition of clast VI, it becomes almost identical to the melt of experiment DW10, which corresponds to a degree of melting of $\sim 10 \mathrm{wt} . \%\left(1300^{\circ} \mathrm{C}\right)$ at $1.5 \mathrm{GPa}$. When $\sim 12 \mathrm{wt} . \%$ of olivine is added to the composition of the vitrophyre, it approaches the composition of another experimental melt (DW04), which corresponds to a degree of melting of $\sim 30 \mathrm{wt} . \%\left(1400^{\circ} \mathrm{C}\right)$ at $1.5 \mathrm{GPa}$. The basaltic material that was incorporated in the regolith breccias might thus be derived from the PMM and represent near-primary melts formed at a depth of $\sim 135 \mathrm{~km}$.

\subsubsection{Shergottites: high $\mathrm{CaO} / \mathrm{Al}_{2} \mathrm{O}_{3}$ basalts}

Shergottites are the most abundant group of martian meteorites and the only group that contains olivine-bearing basalts. Some shergottites are believed to represent primitive melts (Gross et al., 2013, 2011; Musselwhite et al., 2006; Peslier et al., 2010). However, they exhibit a significant depletion in aluminum when compared to virtually all other analyses of martian rocks (McSween et al., 2009). They plot close to our melts produced at high degrees of melting (25-50 wt.\%) on projection diagrams (Fig. 6). Shergottites also appear enriched in the clinopyroxene component and poorer in the plagioclase component relative to experimental melts. This reflects the high $\mathrm{CaO} / \mathrm{Al}_{2} \mathrm{O}_{3}$ ratio that is characteristic of shergottite bulk-rock compositions. The low $\mathrm{Al}_{2} \mathrm{O}_{3}$ content of shergottites seems in better agreement with the melting of a refractory mantle source. The melting is more likely to have occurred at high pressure $(>2 \mathrm{GPa})$ in order to produce the picritic compositions (i.e. high $\mathrm{MgO}$ contents) that are characteristic of shergottites at more realistic degrees of melting ( $<30 \mathrm{wt} . \%$ ).

The influence of water has been invoked to account for the relatively high $\mathrm{SiO}_{2}$ content of some shergottites (Balta and McSween, 2013). However, our experiments show that liquids rich in $\mathrm{MgO}$ (15-20 wt.\%) with 48 to 52 wt.\% of $\mathrm{SiO}_{2}$ are produced under nominally anhydrous conditions ( $<0.5 \mathrm{wt} . \%)$.

\subsection{The Mg-number of martian mantle reservoirs}

Most recent geochemical and geophysical models of the martian mantle converge towards a Mg\# of 75-77 (Taylor, 2013). The starting composition used for our experiments is on the low end with a Mg\# of 75 (Dreibus and Wanke, 1984). From 7 to 25 wt.\% melting, melts have $\mathrm{Mg \#}$ ranging from 50 to 55 and are in equilibrium with olivine containing 74 to 78 mol.\% forsterite (Fo). Olivine megacrysts in LAR 06319 and NWA 1068, the most primitive enriched shergottites, have Fo contents that reach 77 mol.\% (Basu Sarbadhikari et al., 2009). After 15 to 25 wt.\% melting, the residual assemblages (Mg\# 77-79) contain an olivine with Fo76-78, similar to the olivines that would have initially crystallized from LAR 06319, NWA 1068 and the parental melt of the Adirondack basalts. This indicates that the mantle sources of enriched shergottites and Adirondack-class basalts might have a similar $\mathrm{FeO} / \mathrm{MgO}$ ratio to that of the PMM. 
The primitive depleted shergottites contain olivine as magnesian as $\mathrm{Fo}_{86}$ (Usui et al., 2008), which could be found in the residue of the PMM only after more than 50 wt.\% melting. Such extensive melting is invoked for the production of komatiites on Earth but is unlikely for depleted shergottites due to their relatively young crystallization age. In addition, as discussed in the previous section, the high $\mathrm{CaO} / \mathrm{Al}_{2} \mathrm{O}_{3}$ ratio of shergottites is not in agreement with our experimental melts. In order to produce melts with 18-20 wt.\% of $\mathrm{MgO}$ in equilibrium with $\mathrm{Fo}_{86}$ olivine at a low degree of melting (8-15 wt.\%) and at low pressure (1.2 GPa; Musselwhite et al., 2006), the mantle source must have a Mg\# in the range 82-85.

From the study of shergottites and Adirondack basalts, we expect mantle sources on Mars to vary in composition by at least 7 units of Mg\# (75-82). To produce this level of heterogeneity from the PMM, parts of the mantle must have been affected by more than 50 wt.\% melting during one or several events. However, such refractory reservoirs are expected to produce melts with lower concentration of incompatible elements relative to the primitive depleted shergottites (Gross et al., 2011; Usui et al., 2008). The crystallization of a magma ocean might more easily produce mantle sources with elevated Mg\# (Elkins-Tanton et al., 2003).

\section{Conclusion}

Low degree melts produced from the primitive martian mantle between 0.5 and $2.2 \mathrm{GPa}$ cover a wide compositional range from benmoreites and mugearites at low pressure to hawaiites and basanites at higher pressure. Melt compositions converge towards basalt at higher extents of melting. Due to its large diversity, the experimental dataset can be directly compared to most martian rocks that could represent primitive silicate liquid compositions. Among those, the Adirondack-class basalts and basaltic clasts from NWA 7034/7533 are close in composition to experimental trends and they can be inferred to derive from the PMM. However, other mantle reservoirs and the influence of fractional crystallization are necessary to retrace the crystallization history of other igneous rocks from the martian crust. The alkaline rocks from Columbia Hills are depleted in $\mathrm{CaO}$ relative to melts from the PMM, and we suspect that $\mathrm{Al}_{2} \mathrm{O}_{3}$ is not distributed homogeneously in their mantle source. Jake_M might be derived from an alkali-rich melt from the PMM but fractional crystallization must have occurred to explain its extreme $\mathrm{K}_{2} \mathrm{O}$ content. Shergottites have higher $\mathrm{CaO} / \mathrm{Al}_{2} \mathrm{O}_{3}$ compared to melts from the PMM, and the depleted sub-group must derive from a more magnesian source with a Mg\# of 82-84. Experimental melts from a nominally dry PMM cannot account for the composition of the entire collection of martian basalts and alkaline rocks, but rather represent a benchmark for the study of other igneous processes and mantle heterogeneities.

\section{Acknowledgements}

MC was an Aspirant Fellow of the F.R.S.-FNRS when the study was conducted. This study was funded by a grant from the PNP program of CNRS-INSU to EM, and a "Tournesol" Hubert Curien Partnership between Liège and Clermont-Ferrand universities. This is Laboratory of Excellence ClerVolc contribution Number 162. BC was supported by a Back to Belgium Grant of the Belgian Science Policy and by the Humboldt Foundation. TLG was supported by NASA Grant NNG06G167G. We thank Alexandra Andrews, Stephanie M. Brown, Ben Mandler and two anonymous reviewers for their helpful comments on the manuscript.

\section{Appendix A. Supplementary material}

Supplementary material related to this article can be found online at http://dx.doi.org/10.1016/j.epsl.2015.06.056.

\section{References}

Agee, C.B., Draper, D.S., 2004. Experimental constraints on the origin of Martian meteorites and the composition of the Martian mantle. Earth Planet. Sci. Lett. 224, 415-429.

Agee, C.B., et al., 2013. Unique meteorite from Early Amazonian Mars: water-rich basaltic breccia Northwest Africa 7034. Science 339, 780-785.

Albarede, F., 2009. Volatile accretion history of the terrestrial planets and dynamic implications. Nature 461, 1227-1233.

Baker, M.B., Stolper, E.M., 1994. Determining the composition of high-pressure mantle melts using diamond aggregates. Geochim. Cosmochim. Acta 58, 2811-2827.

Balta, J.B., McSween, H.Y., 2013. Water and the composition of Martian magmas. Geology 41, 1115. http://dx.doi.org/10.1130/G34714.1.

Baratoux, D., Toplis, M.J., Monnereau, M., Gasnault, O., 2011. Thermal history of Mars inferred from orbital geochemistry of volcanic provinces. Nature 472, 338-341.

Barrat, J.A., Jambon, A., Bohn, M., Gillet, P., Sautter, V., Gopel, C., Lesourd, M., Keller F., 2002. Petrology and chemistry of the picritic shergottite North West Africa 1068 (NWA 1068). Geochim. Cosmochim. Acta 66, 3505-3518.

Basu Sarbadhikari, A., Day, J.M.D., Liu, Y., Rumble, D., Taylor, L.A., 2009. Petrogenesis of olivine-phyric shergottite Larkman Nunatak 06319: implications for enriched components in Martian basalts. Geochim. Cosmochim. Acta 73, 2190-2214.

Bertka, C.M., Fei, Y., 1997. Mineralogy of the Martian interior up to core-mantle boundary pressures. J. Geophys. Res. 102, 5251-5264.

Bertka, C.M., Holloway, J.R., 1993. Pigeonite at solidus temperatures: implications for partial melting. J. Geophys. Res., Solid Earth 98, 19755-19766.

Bertka, C.M., Holloway, J.R., 1994a. Anhydrous partial melting of an iron-rich mantle 1: subsolidus phase assemblages and partial melting phase-relations at 10 to 30 kbar. Contrib. Mineral. Petrol. 115, 313-322.

Bertka, C.M., Holloway, J.R., 1994b. Anhydrous partial melting of an iron-rich mantle 2: primary melt compositions at 15 kbar. Contrib. Mineral. Petrol. 115, 323-338.

Breuer, D., Spohn, T., 2006. Viscosity of the Martian mantle and its initial temperature: constraints from crust formation history and the evolution of the magnetic field. Planet. Space Sci. 54, 153-169.

Carter, J., Poulet, F., 2013. Ancient Plutonic processes on Mars inferred from the detection of possible anorthositic terrains. Nat. Geosci. 6, 1008-1012.

Christensen, P.R., et al., 2005. Evidence for magmatic evolution and diversity on Mars from infrared observations. Nature 436, 504-509.

Debaille, V., Brandon, A.D., O'Neill, C., Yin, Q.Z., Jacobsen, B., 2009. Early martian mantle overturn inferred from isotopic composition of nakhlite meteorites. Nat. Geosci. 2, 548-552.

Dreibus, G., Wanke, H., 1984. Accretion of the Earth and the inner planets. In: Proc. 27th International Geological Congress, vol. 11, pp. 1-20.

Dreibus, G., Wanke, H., 1985. Mars, a volatile-rich planet. Meteoritics 20, 367-381.

Elkins-Tanton, L.T., Parmentier, E.M., Hess, P.C., 2003. Magma ocean fractional crystallization and cumulate overturn in terrestrial planets: implications for Mars. Meteorit. Planet. Sci. 38, 1753-1771.

Elkins-Tanton, L.T., Zaranek, S.E., Parmentier, E.M., Hess, P.C., 2005. Early magnetic field and magmatic activity on Mars from magma ocean cumulate overturn. Earth Planet. Sci. Lett. 236, 1-12.

Filiberto, J., Dasgupta, R., 2011. $\mathrm{Fe}^{2+}-\mathrm{Mg}$ partitioning between olivine and basaltic melts: applications to genesis of olivine-phyric shergottites and conditions of melting in the Martian interior. Earth Planet. Sci. Lett. 304, 527-537.

Foley, C.N., Economou, T., Clayton, R.N., 2003. Final chemical results from the Mars Pathfinder alpha proton X-ray spectrometer. J. Geophys. Res., Planets 108, 8096.

Francis, D., 2011. Columbia Hills - an exhumed layered igneous intrusion on Mars? Earth Planet. Sci. Lett. 310, 59-64.

Gaetani, G.A., 1998. Igneous petrology. Science 282, 1834-1835.

Gaetani, G.A., Grove, T.L., 1998. The influence of water on melting of mantle peridotite. Contrib. Mineral. Petrol. 131, 323-346.

Gross, J., Filiberto, J., Herd, C.D.K., Daswani, M.M., Schwenzer, S.P., Treiman, A.H. 2013. Petrography, mineral chemistry, and crystallization history of olivinephyric shergottite NWA 6234: a new melt composition. Meteorit. Planet. Sci. 48, 854-871.

Gross, J., Treiman, A.H., Filiberto, J., Herd, C.D.K., 2011. Primitive olivine-phyric shergottite NWA 5789: petrography, mineral chemistry, and cooling history imply a magma similar to Yamato-980459. Meteorit. Planet. Sci. 46, 116-133.

Grove, T., 1993. Corrections to expressions for calculating mineral components in "Origin of calc-alkaline series lavas at Medicine Lake Volcano by fractionation, assimilation and mixing" and "Experimental petrology of normal MORB near the Kane fracture zone: $22^{\circ}-25^{\circ} \mathrm{N}$, Mid-Atlantic Ridge”. Contrib. Mineral. Petrol. 114, 422-424.

Halliday, A.N., Porcelli, D., 2001. In search of lost planets - the paleocosmochemistry of the inner solar system. Earth Planet. Sci. Lett. 192, 545-559.

Hays, J.F., 1966. Stability and properties of the synthetic pyroxene $\mathrm{CaAl}_{2} \mathrm{SiO}_{6}$. Am. Mineral. 51, 1524-1529.

Hirschmann, M.M., 2000. Mantle solidus: experimental constraints and the effects of peridotite composition. Geochem. Geophys. Geosyst. 1, 1042.

Hirschmann, M.M., Baker, M.B., Stolper, E.M., 1998. The effect of alkalis on the silica content of mantle-derived melts - NMR, Raman, and infrared spectroscopy. Geochim. Cosmochim. Acta 62, 883-902. 
Holloway, J.R., Pan, V., Gudmundsson, G., 1992. High-pressure fluid-absent melting experiments in the presence of graphite - oxygen fugacity, ferric ferrous ratio and dissolved $\mathrm{CO}_{2}$. Eur. J. Mineral. 4, 105-114.

Humayun, M., et al., 2013. Origin and age of the earliest Martian crust from meteorite NWA 7533. Nature 503, 513-516.

Khan, A., Connolly, J.A.D., 2008. Constraining the composition and thermal state of Mars from inversion of geophysical data. J. Geophys. Res. 113, E07003.

Kinzler, R.J., 1997. Melting of mantle peridotite at pressures approaching the spinel to garnet transition: application to mid-ocean ridge basalt petrogenesis. J. Geophys. Res., Solid Earth 102, 853-874.

Kinzler, R.J., Grove, T.L., 1992. Primary magmas of mid-ocean ridge basalts 1. Experiments and methods. J. Geophys. Res. 97, 6885-6906.

Krawczynski, M.J., Olive, J.L., 2011. A new fitting algorithm for petrological massbalance problems. In: American Geophysical Union, Fall Meeting 2011, abstract \#V53B-2613.

Laporte, D., Toplis, M., Seyler, M., Devidal, J.-L., 2004. A new experimental technique for extracting liquids from peridotite at very low degrees of melting: application to partial melting of depleted peridotite. Contrib. Mineral. Petrol. 146, 463-484.

Lodders, K., Fegley Jr., B., 1997. An oxygen isotope model for the composition of Mars. Icarus 126, 373-394.

Matsukage, K.N., Nagayo, Y., Whitaker, M.L., Takahashi, E., Kawasaki, T., 2013. Melting of the Martian mantle from 1.0 to 4.5 GPa. J. Mineral. Petrol. Sci. 108, 201-214.

McCubbin, F.M., Hauri, E.H., Elardo, S.M., Vander Kaaden, K.E., Wang, J., Shearer, C.K. 2012. Hydrous melting of the martian mantle produced both depleted and enriched shergottites. Geology 40, 683. http://dx.doi.org/10.1130/G33242.1.

McCubbin, F.M., et al., 2015. Composition of fine-grained bulk matrix and protobreccia clast matrix in Northwest Africa 7034: implications for the composition of the martian crust. In: 46th Lunar and Planet. Sci. Conference, p. 1723.

McSween, H.Y., Grove, T.L., Wyatt, M.B., 2003. Constraints on the composition and petrogenesis of the Martian crust. J. Geophys. Res., Planets 108, 5135.

McSween, H.Y., et al., 2006a. Alkaline volcanic rocks from the Columbia Hills, Gusev Crater, Mars. J. Geophys. Res., Planets 111, E09S91.

McSween, H.Y., et al., 2006b. Characterization and petrologic interpretation of olivine-rich basalts at Gusev Crater, Mars. J. Geophys. Res., Planets 111, E02S10.

McSween, H.Y., Taylor, G.J., Wyatt, M.B., 2009. Elemental composition of the Martian crust. Science 324, 736-739.

Médard, E., McCammon, C.A., Barr, J.A., Grove, T.L., 2008. Oxygen fugacity, temperature reproducibility, and $\mathrm{H}_{2} \mathrm{O}$ contents of nominally anhydrous piston-cylinder experiments using graphite capsules. Am. Mineral. 93, 1838-1844.

Médard, E., Schmidt, M., Schiano, P., 2004. Liquidus surfaces of ultracalcic primitive melts: formation conditions and sources. Contrib. Mineral. Petrol. 148, 201-215.

Ming, D.W., et al., 2008. Geochemical properties of rocks and soils in Gusev Crater, Mars: results of the Alpha Particle X-Ray Spectrometer from Cumberland Ridge to Home Plate. J. Geophys. Res., Planets 113, E12S39.

Misawa, K., 2004. The Yamato 980459 olivine-phyric shergottite consortium. Antarct. Meteor. Res. 17, 1-12.

Monders, A.G., Médard, E., Grove, T.L., 2007. Phase equilibrium investigations of the Adirondack class basalts from the Gusev Plains, Gusev Crater, Mars. Meteorit. Planet. Sci. 42, 131-148.

Morgan, J.W., Anders, E., 1979. Chemical composition of Mars. Geochim. Cosmochim. Acta 43, 1601-1610.

Musselwhite, D.S., Dalton, H.A., Kiefer, W.S., Treiman, A.H., 2006. Experimental petrology of the basaltic shergottite Yamato-980459: implications for the thermal structure of the Martian mantle. Meteorit. Planet. Sci. 41, 1271-1290.

Nekvasil, H., McCubbin, F.M., Harrington, A., Elardo, S., Lindsley, D.H., 2009. Linking the Chassigny meteorite and the Martian surface rock Backstay: insights into igneous crustal differentiation processes on Mars. Meteorit. Planet. Sci. 44, 853-869.

O'Hara, M.J., 1968. The bearing of phase equilibria studies in synthetic and natural systems on the origin and evolution of basic and ultrabasic rocks. Earth-Sci. Rev. 4, 69-133.

Peslier, A.H., Hnatyshin, D., Herd, C.D.K., Walton, E.L., Brandon, A.D., Lapen, T.J., Shafer, J.T., 2010. Crystallization, melt inclusion, and redox history of a Martian meteorite: olivine-phyric shergottite Larkman Nunatak 06319. Geochim. Cosmochim. Acta 74, 4543-4576.

Plesa, A.C., Tosi, N., Breuer, D., 2014. Can a fractionally crystallized magma ocean explain the thermo-chemical evolution of Mars? Earth Planet. Sci. Lett. 403 225-235.

Pouchou, J.L., Pichoir, F., 1984. New model for quantitative x-ray microanalysis. Part I: application to the analysis of homogeneous samples. Rech. Aérosp., 13-38 (English edition).

Rogers, A.D., Nekvasil, H., 2015. Feldspathic rocks on Mars: compositional constraints from infrared spectroscopy and possible formation mechanisms. Geophys. Res. Lett. http://dx.doi.org/10.1002/2015GL063501.

Sack, R., Ghiorso, M., 1989. Importance of considerations of mixing properties in establishing an internally consistent thermodynamic database: thermochemistry of minerals in the system $\mathrm{Mg}_{2} \mathrm{SiO}_{4}-\mathrm{Fe}_{2} \mathrm{SiO}_{4}-\mathrm{SiO}_{2}$. Contrib. Mineral. Petrol. 102 41-68.

Sanloup, C., Jambon, A., Gillet, P., 1999. A simple chondritic model of Mars. Phys. Earth Planet. Inter. 112, 43-54.

Santos, A.R., Agee, C.B., McCubbin, F.M., Shearer, C.K., Burger, P.V., Tartèse, R., Anand, M., 2015. Petrology of igneous clasts in Northwest Africa 7034: implications for the petrologic diversity of the martian crust. Geochim. Cosmochim. Acta 157, $56-85$.

Sautter, V., et al., 2014. Igneous mineralogy at Bradbury Rise: the first ChemCam campaign at Gale crater. J. Geophys. Res., Planets 119. http://dx.doi.org/ 10.1002/2013JE004472.

Scheinberg, A., Elkins-Tanton, L.T., Zhong, S.J., 2014. Timescale and morphology of Martian mantle overturn immediately following magma ocean solidification. J. Geophys. Res., Planets 119. http://dx.doi.org/10.1002/2013JE004496.

Schmidt, M.E., et al., 2014. Geochemical diversity in first rocks examined by the Curiosity Rover in Gale Crater: evidence for and significance of an alkali and volatile-rich igneous source. J. Geophys. Res., Planets 119, 64-81.

Stolper, E.M., et al., 2013. The petrochemistry of Jake_M: a Martian mugearite. Science 341,1239463

Takahashi, E., Kushiro, I., 1983. Melting of a dry peridotite at high pressures and basalt magma genesis. Am. Mineral. 68, 859-879.

Taylor, G.J., 2013. The bulk composition of Mars. Chem. Erde-Geochem. 73, 401-420

Toplis, M.J., 2005. The thermodynamics of iron and magnesium partitioning between olivine and liquid: criteria for assessing and predicting equilibrium in natural and experimental systems. Contrib. Mineral. Petrol. 149, 22-39.

Udry, A., Lunning, N.G., McSween Jr., H.Y., Bodnar, R.J., 2014. Petrogenesis of a vitrophyre in the martian meteorite breccia NWA 7034. Geochim. Cosmochim. Acta 141, 281-293.

Usui, T., McSween, H.Y., Floss, C., 2008. Petrogenesis of olivine-phyric shergottite Yamato 980459, revisited. Geochim. Cosmochim. Acta 72, 1711-1730.

Wasylenki, L.E., Baker, M.B., Kent, A.J.R., Stolper, E.M., 2003. Near-solidus melting of the shallow upper mantle: partial melting experiments on depleted peridotite. J. Petrol. 44, 1163-1191.

Wray, J.J., Hansen, S.T., Dufek, J., Swayze, G.A., Murchie, S.L., Seelos, F.P., Skok, J.R Irwin III, R.P., Ghiorso, M.S., 2013. Prolonged magmatic activity on Mars inferred from the detection of felsic rocks. Nat. Geosci. 6, 1013-1017.

Zipfel, J., et al., 2011. Bounce Rock - a shergottite-like basalt encountered at Meridiani Planum, Mars. Meteorit. Planet. Sci. 46, 1-2. 